\title{
La imagen de Claudio López, segundo marqués de Comillas
}

\section{The image of Claudio López, second Marquis of Comillas}

\author{
Miguel Ángel Aramburu-Zabala Higuera
}

\author{
Universidad de Cantabria \\ Departamento de Historia moderna y contemporánea \\ Facultad de Filosofía y Letras. Edificio Interfacultativo \\ Avda. de los Castros, 52. 39005 - Santander \\ aramburm@unican.es
}

ORCID: https://orcid.org/ 0000-0001-8678-7040

Fecha de envío: 01/10/2018 Aceptado: 21/10/2109

Referencia: Santander. Estudios de Patrimonio, 2 (2019), pp. 13-64

DOI: https://doi.org/10.22429/Euc2019.sep.02.01

ISSN 2605-4450 (ed. impresa) / ISSN 2605-5317 (digital)

(c) $(1) \Theta$

Este trabajo se enmarca en el Proyecto de investigación I+D del Ministerio de Economía, Industria y Competitividad HAR2016-77254-P

Resumen: Claudio López Bru, segundo marqués de Comillas, muestra en el arte la contradicción entre el rechazo íntimo a la exhibición pública de los honores recibidos y la necesidad de mostrarse en cada ocasión de acuerdo a las reglas sociales usualmente aceptadas y, sobre todo, el deber de honrar a las instituciones con las que se relaciona, sea la Iglesia, la monarquía, la familia o sus empresas. El traje de gala, uniformes y medallas distinguen sus retratos de los mucho más austeros de su padre, y la idea religiosa está siempre presente en el arte que patrocina, cercano ideológicamente al Círculo de San Lucas de Barcelona.

Palabras clave: Comillas; marqués; patronazgo; pintura; escultura; retrato.

Abstract: Claudio López Bru, second Marquis of Comillas, shows the contradiction in art between the intimate rejection of the public exhibition of the honours received, the need to show always himself according to the commonly accepted social rules and, above all, the duty to honour the institutions with which it is related, such as the Church, the monarchy, the family or its companies. The gala dress, uniforms and medals distinguish his portraits from the much more austere ones of his father. Otherwise, the religious idea is always present in the art that he sponsors, showing ideological affinity with the Circle of San Lucas in Barcelona.

Keywords: Comillas; marquis; patronage; painting; sculpture; portrait.

El primer marqués de Comillas, Antonio López y López, centró su vida en conseguir levantar un gran grupo económico, primero en Cuba y después en Barcelona. Poco interesado en el arte, se dejaría en este campo asesorar por su hijo Claudio López Bru, que ya pudo recibir una larga formación académica e internacional, y que, además de continuar los negocios paternos, mo- 


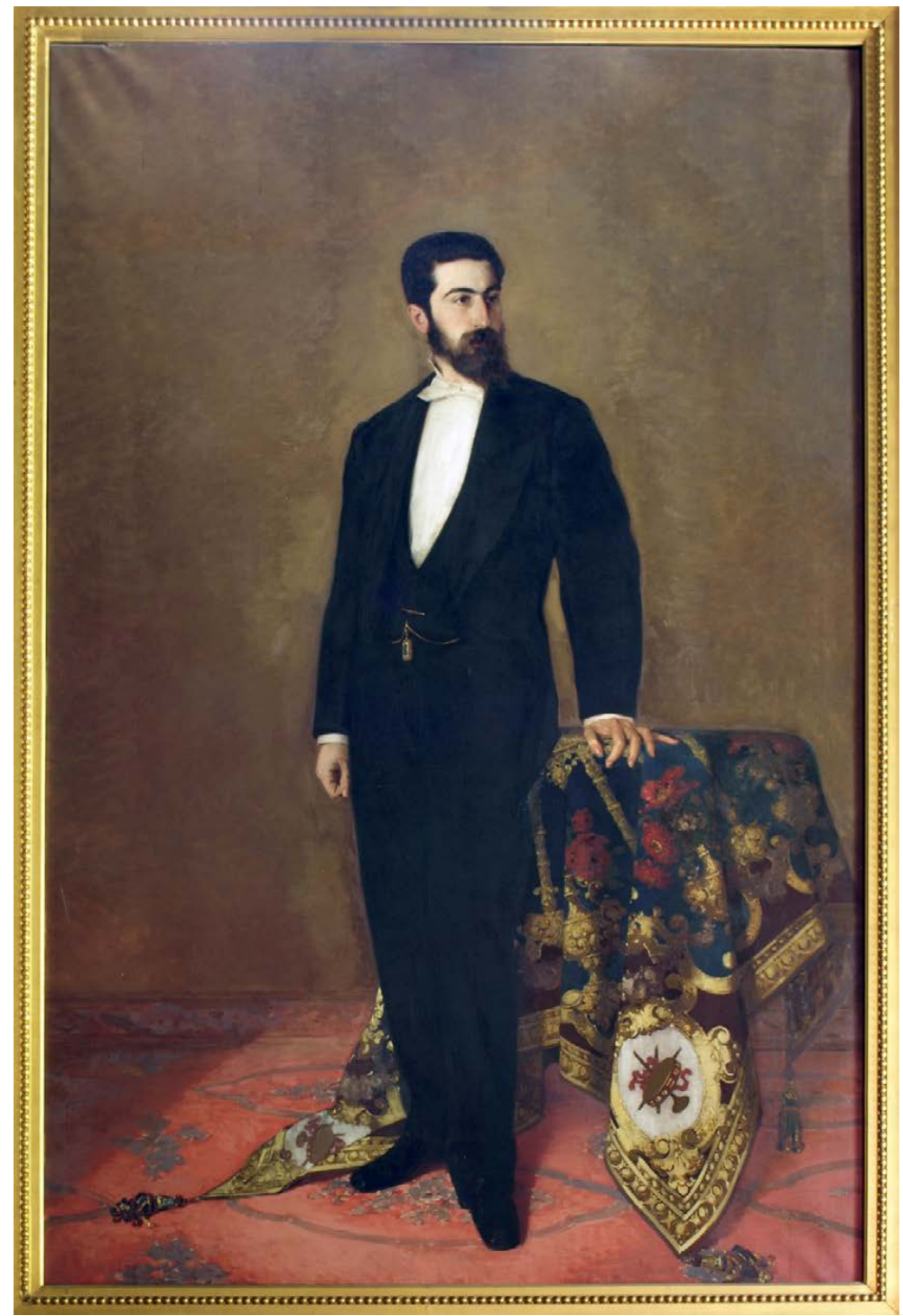

Fig. 1. Claudio López Bru. José Sánchez y Sánchez. 1874. Palacio de Sobrellano.

Comillas

dernizándolos y ampliándolos, era capaz de tener ideas estéticas, religiosas, sociales o políticas sofisticadas.

Claudio López Bru nació en Barcelona el 14 de mayo de 1853, hijo de Antonio y de Luisa; cursó estudios de Derecho entre 1869 y 1873, viajando posteriormente por diversos países europeos; y en 1875 se estableció por un tiempo en Cádiz para encargarse allí de la Compañía Trasatlántica. En 1881 contrajo matrimonio con María Gayón, con la que no tendría descendencia; 


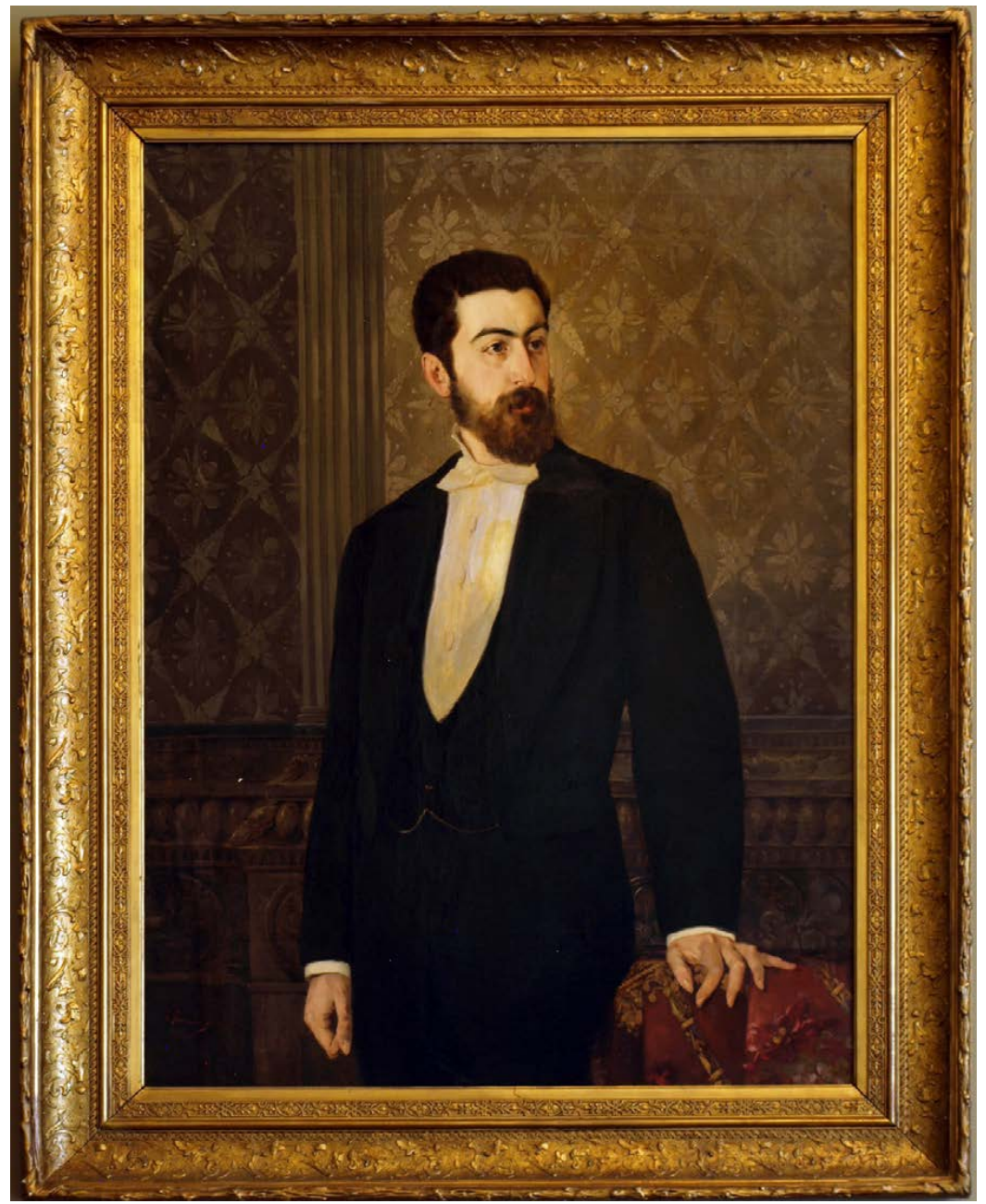

Fig. 2. Claudio López Bru. Eliecer Jaureguízar. Palacio Moja. Barcelona

y tenía 29 años cuando en 1883 se hacía cargo del conjunto empresarial heredado de su padre'.

1 GASCÓN, Miguel, Luz sin sombra. El Marqués de Comillas, Comillas, Sal Terrae, 1925. ASÚA, Miguel de, El Marqués de Comillas. Biografía, Cádiz, Real Academia Hispanoamericana de Ciencias y Artes, 1926. BAYLE, Constantino, El segundo marqués de Comillas Don Claudio López Bru, Madrid, Razón y Fe, 1928. NEVARES MARCOS, Sisinio, El patrono ejemplar. Una obra maestra de Acción Social, Madrid, Razón y Fe, 1936. FERNÁNDEZ REGATILLO, Eduardo, Posiciones y artículos para el proceso sobre la fama de Santidad, virtudes y milagros del siervo de Dios Claudio López Brú, marqués de Comillas, Santander y Madrid, Aldus, 1943. FERNÁNDEZ REGATILLO, Eduardo, "Causa de beatificación del Marqués de Comillas", Sal Terrae, XXXV (dic. 1947), pp. 804-814. FERNÁNDEZ REGATILLO, Eduardo, Un marqués modelo. El Siervo de Dios Claudio López Bru, segundo Marqués de Comillas, Santander, Sal Terrae, 1950. MAURA Y GAMAZO, 
Elogiado por muchos, también fue criticado, no sólo por sus actos sino también por los de su padre ${ }^{2}$. Cuando en el diario republicano La Autonomía se escribía el 16 de septiembre de 1897 que con la guerra de Cuba la Compañía Trasatlántica ganaría 100 millones de pesetas, se apostillaba que

"la guerra habrá sido para el piadoso marqués una bendición. Bien es verdad que en eso no hace el hijo de don Antonio López más que continuar una tradición de familia, pues su padre se enriqueció en Cuba allá cuando la ignominia de la esclavitud subsistía; y como dice el refrán, 'el que lo hereda, no lo hurta" 3 .

Aunque Claudio López no emigró a América, se proyecta sobre él la tradicional imagen negativa del indiano, añadida a la de opulento capitalista, y por tanto, explotador. Por ejemplo, cuando se describía la finca de caza de Navalmoral de la Mata (Cáceres), que Claudio hereda de su padre, en El Diluvio el 25 de octubre de 1919, Ángel Samblancant y Salanova aprovecha para presentar a Claudio López como un señor terrateniente que explota las dehesas en arrendamiento: "El marqués de Comillas, que, además de naviero y minero y usurero, es terrateniente, posee en Navalmoral veintisiete dehesas, de cuyo arrendamiento saca al año unos ochenta mil duros" ${ }^{4}$. Esta imagen contrasta notablemente con los inmensos elogios y homenajes que él, como su padre, recibió en vida y que continuaron después de su fallecimiento.

El homenaje más espectacular lo constituye el monumento que se le erigió en Cádiz, en vida de Claudio López. Según escribió Gabriel Ricardo España en 1924 en el libro dedicado al monumento, "el marqués de Comillas ha sido y es el primer enemigo de esta apoteosis en mármoles y bronce,

Gabriel, Pequeña historia de una grandeza. El Marqués de Comillas, Barcelona, José Porter, 1949. PENSADO, Berta, El Marqués de Comillas, Madrid, Temas Españoles 83, 1954. PAPÀSOGLI, Giorgio, Il Marchese di Comillas, Torino, Marietti Editori, 1959. PAPÀSOGLI, Giorgio, El marqués de Comillas: Don Claudio López Bru, Madrid, Publicaciones de la Universidad Pontificia Comillas, 1984. KENT, Conrad, “Claudio López y Eusebio Güell: industriales como forjadores de cultura", en CIPLIJAUSKAITÉ, Biruté y MAURER, Christopher (eds.), La voluntad de humanismo. Homenaje a Juan de Marichal, Barcelona, Anthropos, 1990, pp. 107-120. RODRIGO ALHARILLA, Martín, Los Marqueses de Comillas, 1817-1925. Antonio y Claudio López, Madrid, Lid, 2001. FAES DÍAZ, Enrique, "Poder político y poder económico en la Restauración: una interpretación divina (la singular formulación del segundo Marqués de Comillas", Historia y política. Ideas, procesos y movimientos sociales, 9 (2003), pp. 9-39. FAES DÍAZ, Enrique, Claudio López Bru, Marqués de Comillas, Madrid, Marcial Pons, 2009.

2 En El Redactor de Santiago de Cuba del 8 de junio de 1851 se publicaba el siguiente anuncio: “Compran negros de ambos secsos en partidas y sueltos al contado; los Sers. Antonio Lopez y Hermano, calle de la Marina número 38 8".

3 La Autonomía, 846 (16 de septiembre de 1897), p. 2.

4 El Diluvio, 61, 211 (25 de octubre de 1919), p. 11. 
que todos aplauden y que él sinceramente deplora" ${ }^{5}$. Esta contradicción de alguien en quien se alaba su "modestia" pero que recibe continuos honores, que al fin acepta, fue explicada señalando que Claudio López debía ceder su natural humildad ante razones de fuerza mayor. En efecto, a lo largo de su vida Claudio López debía ceder ante la necesidad del deber de honrar a su padre (que es un precepto religioso); o ante las necesidades de la Iglesia (para manifestar la Gloria de Dios), de sus empresas (que tenían que mostrar la autoridad jerárquica que las regían) o de grandes ideas patrióticas (caso del monumento de Cádiz, con la relación entre España y América). Una comparación entre los retratos más conocidos de Antonio López, de austera vestimenta negra y sin condecoración alguna, con los de Claudio pintados al óleo, plenos de color y cargados de condecoraciones, indica que la modestia era un concepto que hemos de rastrear más allá de las apariencias, un concepto más interior, puesto que él aparece muchas veces rehuyendo los oropeles -se ausentaba de los homenajes que recibía- y son varios los biógrafos del marqués que coinciden en este mismo concepto de la modestia como algo esencial en Claudio López.

\section{LOS PRIMEROS RETRATOS}

En el contexto de formar una galería de retratos pintados de gran formato de los varones de la familia López (Antonio López y sus hijos Antonio y Claudio) se hallan dos retratos de un Claudio López joven estrechamente relacionados, pintados por Eliecer Jaureguízar (Fig. 1) y José Sánchez y Sánchez (Fig. 2). Estos dos pintores tienen una trayectoria contrapuesta: mientras que Jaureguízar nace en Santander y se forma en Cádiz ${ }^{6}$, Sánchez es un pintor andaluz que triunfa en Santander ${ }^{7}$.

El cuadro de Sánchez, de cuerpo entero, fue pintado en 1874 (con 21 años de edad para Claudio), cuando Jaureguízar tenía sólo 18 años. Podría pensarse que a Jaureguízar se le encargó una versión de medio cuerpo del cuadro de Sánchez, y en este encargo tendría algo que ver que su padre, José María de Jaureguízar, era capitán de la Compañía de Antonio López, al igual que su hermano Francisco (Santander, 1850 - 1893, fallecido en la explosión del vapor Cabo Machichaco). Eliecer Jaureguízar casi podría considerarse por tanto miembro de la gran familia de la Compañía Trasatlántica.

5 Monumento al Marqués de Comillas. Memoria descriptiva del Monumento y de los trabajos realizados por la Comisión Organizadora, Cádiz, Rodríguez de Silva, 1924, p. 11.

6 Eliecer Jaureguízar Cagigal había nacido en Santander en 1856; fue discípulo en la Escuela de Bellas Artes de Cádiz, en cuyas exposiciones presentó sus primeros cuadros, y falleció en 1880.

7 GUTIÉRREZ DÍAZ, Francisco, “Un pintor decimonónico afincado en Santander. José Sánchez y Sánchez", Altamira, 73 (2007), pp. 231-256. 


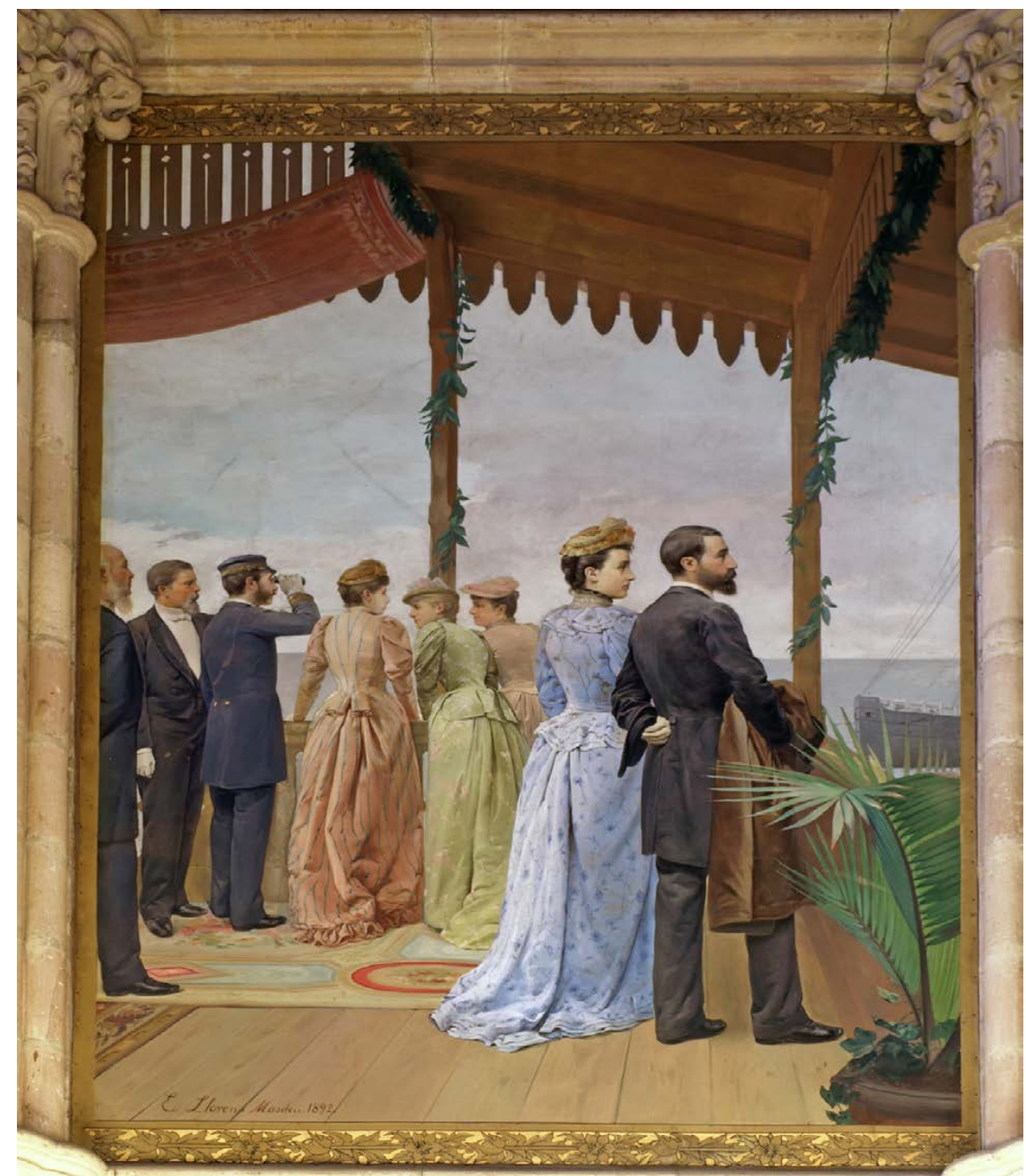

Fig. 3. Presentación de la Escuadra delante del Golfo de Comillas a sus Magestades y Altezas Reales. Agosto de 1881. Eduardo Llorens Masdeu. 1892. Palacio de Sobrellano. Comillas

Ambos cuadros en definitiva muestran la imagen de un elegante y distinguido joven noble barcelonés. Miguel de Asúa, en la biografía que le dedicó en 1926, mencionaba "la elegancia de su figura y la distinción de su actitud y sus maneras, encarnando en los rasgos de su fisonomía noble y atrayente, la tradicional cortesanía, propia del caballero español de todos los tiempos" 8 .

El 23 de marzo de 1881 Claudio López, de 28 años, contrajo matrimonio en Barcelona con María Gayón, que contaba entonces con 17. Pocos meses

8 ASÚA, Miguel de, El Marqués de Comillas..., p. 17. 
después, Claudio recibió de su padre la misión de preparar el alojamiento de la familia real en Comillas, y el 26 de agosto se celebró la presentación de la escuadra de Antonio López, que fue pintada en 1892 por Eduardo Llorens Masdeu, con destino al vestíbulo del palacio de Sobrellano. La escena sitúa a los personajes en "el precioso y elegante kiosko de la Reina (María Cristina), construido al efecto en una eminencia de la costa" ${ }^{\prime \prime}$. Aunque aparentemente los personajes centrales de la escena son el rey, la familia real y Antonio López, Claudio López y María Gayón figuran en primer plano, con sus rostros de perfil, hieráticos, en contraposición a la actitud relajada del resto de los personajes (Fig. 3). La cabeza de Claudio procede de una fotografía que años después se utilizará en grabados que la prensa publicará con cierta asiduidad, hasta constituir una de las imágenes más reconocibles del marqués.

Como sabemos, la serenidad que desprende la escena no se corresponde con la realidad, pues fue un día particularmente desapacible, con una "galerna acompañada de espantosa lluvia". A la derecha del kiosko se ven en la pintura los barcos de la "escuadra" de Antonio López" ${ }^{10}$. El Almanaque del Diario de Barcelona para el año 1882 (p. 28) menciona la revista de la escuadra para el día 27:

“El 27, maniobran delante de SS. MM. Los vapores Antonio López, España, Ciudad Condal, Gijón y Puerto Rico de la Sociedad López y C‥ Es la primera vez que los monarcas de España revistan una escuadra de vapores mercantes, que puede competir con cualquier escuadra de guerra, con la circunstancia de ser obra de la actividad e inteligencia de un solo hombre y no del poder del Estado".

La vida familiar de Claudio López y María Gayón aparece en el cuadro de Francisco Miralles "La familia del conde de Güell”, de $1897^{11}$. Francisco Miralles y Galup (Valencia, 1848-Barcelona, 1901) fue discípulo de Ramón Martí y Alsina, en cuyo taller ingresó en 1862, marchando poco después a París, ciudad en la que se instaló por muchos años en 1865, consiguiendo el triunfo como pintor, bien relacionado con los ambientes aristocráticos y artísticos, y de donde no regresaría hasta 1895. Era amigo del conde de Güell,

9 La Época, XXXIII, 10468 (27 de agosto de 1881), p. 2. Sobre las visitas reales y su influencia artística en Comillas, GARCÍA-MARTÍN, Manuel, Comillas modernista, Barcelona, Catalana de Gas, 1993. SAMA, Antonio, "Nuevas noticias sobre el joven Gaudí: los kioskos de Comillas", Boletín de la Institución Libre de Enseñanza, 11 (abril 1991), pp. 37-52.

10 Las maniobras que tenían previsto desarrollar se pueden seguir a través de un libro editado para la ocasión: Plan de señales para la flota de A. López y Comp qu que ha de maniobrar frente a Comillas en presencia de S.M. el Rey, Santander, José M. Martínez, 1881, Biblioteca del Palacio Real de Madrid, VIII/3794.

11 Francisco Miralles: “La familia del conde de Güell”, óleo sobre tabla, 1897. Eusebio Güell, su mujer Isabel López Bru, María Luisa López Bru, María Gayón y Claudio López Bru. Fot. publicada en ARNÚS, María del Mar, Comillas, preludio de la modernidad, Madrid, Electa, 1999, p. 126. 
Eusebio Güell Bacigalupi, marido de Isabel López Bru, hermana de Claudio López, casado con María Gayón. Y así en el cuadro figuran los cuatro, Eusebio, Isabel, Claudio y María, más María Luisa López Bru. Esta pintura, como muchas otras de Miralles, refleja la vida galante y aristocrática hacia 1880.

Un biógrafo de Claudio López, el padre Constantino Bayle escribió de él:

“No era por entonces (1875), ni lo fue nunca, misántropo ni 'beato' asustadizo, que abominara como pecaminosas cualquiera diversiones: asistía al teatro, pocas veces, y claro es, cuando tenía seguridad de que no se había de ofender al pudor; los saraos, por su posición, no podía rehusarlos: los tomaba como cumplidos, y sólo lo suficiente para cumplir, porque su espíritu de intimidad, de llaneza, se avenía mal con las farsas que de ordinario se representan, aun para fingir la alegría. Contábanle desde Comillas las fiestas de familia, con bailes y teatro y música; todo de puertas adentro, donde todos estaban seguros del cariño de todos; esos regocijos sí le gustaban a Claudio" ${ }^{12}$.

Refiere también el "teatrillo de aficionados" que en los veranos organizaban familiares y amigos, uno de los cuales parece representar el cuadro de Miralles. Sin embargo, cuando se proyectaba la imagen pública de Claudio López se indicaba expresamente que no asistía a "teatros y diversiones públicas o privadas".

El cuadro se inserta en lo que se ha llamado "interiores retratísticos", típicos de finales del siglo XIX y principios del XX, en los que retrato e interior de la vivienda pugnan por el protagonismo en un difícil equilibrio. Se parte de la representación dieciochesca de una conversación o escena trivial, donde se describe minuciosamente un interior lujoso, pero ahora se busca resolver equilibradamente el conflicto entre retrato y fondo. Los representados ya no se sienten incómodos retratados en un interior doméstico privado que comparten hombres y mujeres, cuyos papeles sociales se están redefiniendo. Eusebio Güell domina la escena recostado en un sofá, y, como ha señalado Frances Borzello, "aunque tradicionalmente en el arte el sofá se asocia a las mujeres [...] a partir de mediados de siglo (XIX) empiezan a aparecer hombres en sofás, prueba de la creciente importancia de la vida doméstica para ambos sexos" 13 .

\section{EL GRABADO Y LA IMAGEN DE EMPRESA}

Al hacerse cargo de los negocios heredados de su padre, Claudio López hubo de continuar la actividad propagandística que había llevado a usar el retrato grabado, publicado en la prensa. Claudio López llevó a cabo un férreo control de la prensa, consciente de su importancia. No sólo favoreció a

12 BAYLE, Constantino, El segundo marqués de Comillas..., p. 53.

13 BORZELLO, Frances, En casa. El interior doméstico en el arte, Barcelona, Electa, 2006, p. 134. 


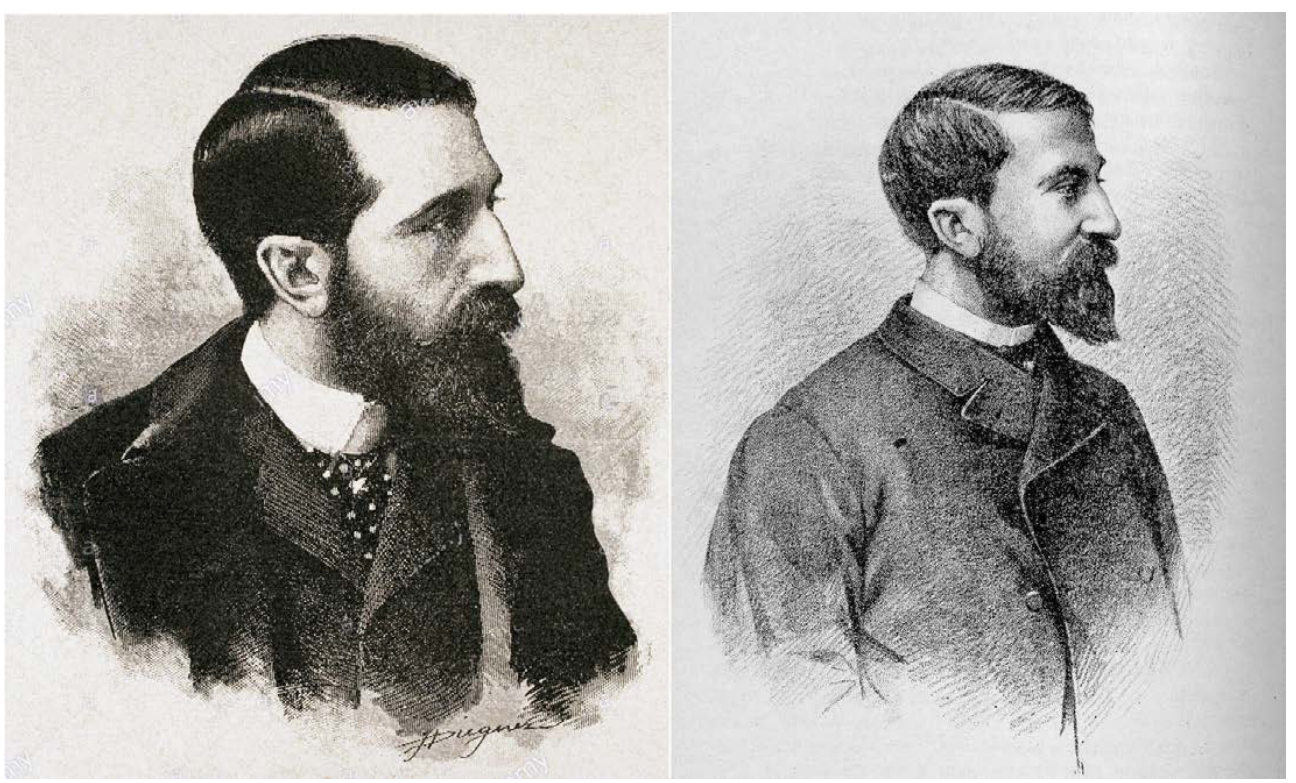

Fig. 4. Claudio López Bru. Joaquín Diéguez. 1890. La Ilustración. Revista hispanoamericana

Fig. 5. Claudio López Bru. 1896. Un viaje a Roma. Peregrinación obrera española

muchas publicaciones, sino que procuró, al decir de sus enemigos, ahogar otras $^{14}$. Consciente Claudio López del poder de la imagen, se crearon en la Compañía Trasatlántica unos "talleres de fotograbado montados por cuenta del excelentísimo señor Marqués de Comillas", de donde saldrían reproducciones fototípicas de los buques de la Compañía, según se señalaba en $1895^{15}$.

Los grabados de Claudio López publicados en la prensa siguen la austeridad que había caracterizado a los retratos de Antonio López. Dos importantes artistas a la vez dibujantes y grabadores, Joaquín Diéguez y Francisco Laporta, en 1890 y 1892 respectivamente, serán los responsables de esta imagen "de empresa" de Claudio López, luego empleadas simplemente como imágenes del marqués, en distintos contextos.

Un grabado con la imagen de Claudio López por Joaquín Diéguez ${ }^{16} f u e$

14 "El verdugo de la prensa" es el título de un artículo escrito en el periódico El Diluvio, enemigo declarado del marqués, 105 (15 de abril de 1903), pp, 11-13.

15 La Atalaya, III, 736 (17 de enero de 1895), p. 2.

16 Joaquín Diéguez y Díaz (Jaén, 1860-1931) fue dibujante, ilustrador, pintor y escritor. Se formó en la Escuela de Bellas Artes de Madrid entre 1879 y 1885, teniendo por maestros, entre otros, a los importantes retratistas Federico de Madrazo y Carlos Luis de Ribera. Residió en Barcelona, donde participó en la Exposición Nacional de Industrias Artísticas en 1892, obteniendo segunda medalla; pasó a París, de nuevo a Barcelona, Suiza, Milán y Madrid. Colaboró con publicaciones como La Ilustración Artística, La Ilustración Hispano-Americana, etc. 
publicado en La Ilustración. Revista hispanoamericana el 29 de junio de 189017, figurando junto a otros retratos de la "Junta de liquidación de la Exposición Universal de Barcelona" (Fig. 4). Muestra a Claudio López con la cabeza girada a la izquierda, vistiendo gabán sobre la chaqueta. Los retratos de Diéguez se caracterizan por el realismo, con un dibujo nítido y preciso, y con "sencillez, fidelidad y elegancia natural"18. Este retrato se volvió a utilizar, como fotograbado, en El Mundo Naval Ilustrado el 1 de julio de 1897; y de nuevo aparece este fotograbado en La Ilustración Artística el 19 de octubre de 1903, donde Teodoro Baró escribía de Claudio López diciendo que

"es de mediana estatura, delgado, rostro de correctas líneas, de mirar dulce y melancólico; negro y alisado cabello, barba a la que comienzan a dar matiz las hebras blancas, no debidas a la incesante, sino a la preocupación de todos los momentos; es sencillo en el vestir"19.

De la misma sesión fotográfica procede otra imagen de Claudio López en que se nos muestra de frente, y cubierto igualmente con gabán y chaqueta, y las manos enguantadas entrecruzadas, que fue publicada en la primera página del Boletín de la Compañía Trasatlántica como suplemento al no 221 de la Revista de navegación y comercio del 15 de enero de 1898. Con este retrato se iniciaba una "Galería Trasatlántica", es decir, una serie de retratos de personajes ligados a dicha Compañía. Se acompañaba de un texto en el que se elogian "las cualidades morales y las condiciones de carácter que avaloran la personalidad" de Claudio López, entre las que se destacan la "infatigable laboriosidad", "muchas virtudes", "rectitud", "solicitud paternal... (con) los suyos", "patriotismo", "honradez", "inteligencia" e "ilustración" 20.

Otra sesión fotográfica daría lugar a un retrato de Claudio López menos enérgico y más reposado, y publicado el 20 de enero de 1892 en la Revista de Navegación y Comercio. El grabado, de Francisco Laporta Valor, se acompañaba de un texto en el que es presentado como presidente de la Compañía Trasatlántica, el Banco Hispano-Colonial, la Compañía General de Tabacos y otras; es el digno heredero de su padre, noble (es Grande de España), pero "hace una vida modesta, sin ostentación", es trabajador, de "carácter afable y bondadoso" y está al servicio "de la religión y de la patria" 21 . El grabado está firmado por Francisco Laporta Valor (Alcoy, 1849-1914), pintor, dibujante

17 La Ilustración. Revista hispanoamericana, XI, 504 (29 de junio de 1890), p. 409.

18 EISMAN LASAGA, Carmen, “La permanencia de la tradición en la pintura de retrato de Joaquín Diéguez", El arte español en épocas de transición, IX Congreso Nacional CEHA, León, 29 de septiembre a 20 octubre 1992, Tomo II, Universidad de León, 1994, pp. 473-480.

19 La Ilustración Artística, XXII, 1138 (19 de octubre de 1903), p. 3.

20 La misma fotografía la publicaría después la revista Mercurio, de Barcelona (1 de septiembre de 1910).

21 Revista de Navegación y Comercio, Madrid, LXXX (20 de enero de 1892), p. 1. 
y grabador ${ }^{22}$. Perteneciente a una saga de fotógrafos y grabadores, estudió en la Escuela de Bellas Artes de San Fernando, y en París aprendió la técnica del heliograbado o fotograbado directo, fundando en Madrid la empresa "Laporta Hnos.", una de las primeras de esta técnica en España, lo que le procuró numerosa clientela ${ }^{23}$. Con el fotograbado o heliografía, que Laporta usa ya en 1880, la imagen impresa resultante se descompone en un alto número de puntos de distinto grosor, engañando al ojo con una gama de grises sombreados, dando una apariencia mucho más real que otras técnicas anteriores, pues la apariencia es de mancha y no de líneas. En este retrato, publicado en 1892, se ha preferido mostrar la cabeza de perfil, vistiendo chaqueta, sin gabán. El perfil de la cabeza queda más nítido que en el grabado de Diéguez al levantar la barbilla, despegándola del cuerpo. La tranquilidad y sosiego que muestra se relaciona con la cabeza de la imagen pintada por Llorens Masdeu en 1889 en el palacio de Sobrellano, y por tanto la fotografía original debe fecharse antes de dicha pintura. Este grabado tuvo éxito y fue reproducido después en otras publicaciones. Bastaba por ejemplo girar un poco la figura, inclinándola hacia atrás, para que representara una actitud más lejana, mirando al horizonte.

Este retrato del marqués fue reproducido como miniatura en un documento importante, el "testimonio" de la "donación y fundación" del Seminario de Comillas a la Santa Sede, copiando la escritura del 10 de junio de 1891. El documento, en 13 pliegos, fue firmado como autor material por Eduardo Balabasquer, quien "lo escribió, dibujó y pintó" según anotó en Madrid el 27 de octubre de 1893. Quiso añadir una acuarela con las armas del Papa, España y el marqués de Comillas, que el propio autor explicó:

“España, guiada por el Sumo Pontífice, nuestro Santísimo Padre Leon trece, y secundada por el esfuerzo de uno de sus más preclaros hijos el Excmo. Sr. Marques de Comillas, abandona la noche de la impiedad para remontar su vuelo hacia los dominios de la fé, de la verdad cristiana y del amor divino"24.

La misma imagen grabada del retrato de Claudio López (pero no como

22 OSSORIO Y BERNARD, Manuel, Galería biográfica de artistas españoles del siglo XIX, vol. I, Madrid, Imprenta de Ramón Moreno, 1868, p. 352. Dedica más espacio a su hermano Enrique Laporta.

23 En 1883, Francisco Laporta fundó, con Julio Puig, la revista Bellas Artes. En Alcoy pintó en varias iglesias y en el teatro principal; y fue catedrático de la Escuela de Bellas Artes de esta ciudad. Hizo pintura religiosa ("Rosa Mística", 1894, etc.). En 1869 ya colaboraba con el grabador Marcelo París y también colaboró con el pintor Antonio Caula.

24 Archivo Histórico de la Universidad Pontificia Comillas (en adelante AHUPC), H-156. Testimonio expedido por Don Francisco Tobar y Vitón, notario y abogado de Madrid. Y "Asunto simbólico para la portada para el testimonio del Excmo. Sr. Marqués de Comillas". En carta de Eduardo Balabasquer a Francisco Tobar el 16 de marzo de 1894, le remite el “Testimonio" y le da instrucciones para el encuadernado. 
fotograbado), y extendiendo la figura hasta el medio cuerpo, figuró en el libro Un viaje a Roma. Peregrinación obrera española..., 1896 (Fig. 5), uno de los varios que conmemoraban la Peregrinación organizada en 1894 por Claudio López en apoyo del Papa. Sabemos que ya en 1894 se había publicado y puesto a la venta un lujoso libro titulado Peregrinación obrera española a Roma, con cubierta de oro y plata y que tenía además de documentos acerca de la peregrinación, retratos, entre otros del Papa, del nuncio Bertoni, el cardenal-arzobispo de Valencia, el obispo de Madrid-Alcalá, los marqueses de Cubas y de Comillas, y monumentos de Roma ${ }^{25}$. En el mismo año de 1894 se publicó el libro del abogado Amando R. Castroviejo Nobajas titulado Peregrinación obrera española a Roma en 1894. De Granada a Roma y regreso. Tres semanas de Peregrinación, con prólogo del doctor don Francisco Javier Simonet, en Granada, imprenta de López Guevara, 1894, que carece de grabados. Y dos años después, el obrero Santiago Guijar y Velasco publicó la experiencia de la peregrinación obrera a Roma de 1894 en el libro titulado Un viaje a Roma. Peregrinación obrera española o sea el triunfo de la Religión, Valladolid, Imprenta de Leonardo Miñón, 1896, que incluye 16 grabados, entre ellos el de Claudio López que reproducimos. En definitiva, era una amplia labor editorial para que la Peregrinación tuviera gran resonancia, y donde la presencia de Claudio López era fundamental ${ }^{26}$.

Otra versión, simplificada, de esta imagen de Claudio López la encontramos en el libro titulado La guerra hispano-yanqui. Álbum episódico, ilustrado con 196 grabados, regalado por La Vanguardia, de Barcelona, tomo XIV, sin fecha (¿1898?). Es un grabado de escasa calidad, recogido en una lámina dentro del álbum que estaba dedicada a los ministros de Marina de la guerra hispano norteamericana de 1898 y que sorprendentemente representa a Claudio López en el centro, presentado como "Sr. Marqués de Comillas. Gerente de la Trasatlántica y auxiliar valiosísimo de los aprestos navales de España", teniendo a su derecha a "D. Segismundo Bermejo, Ministro de Marina de España al empezar la guerra"; y a su izquierda, a "Mr. John D. Long. Ministro de Marina de los Estados Unidos".

De la misma sesión fotográfica de hacia 1889 (o anterior) procede un grabado de Paciano Ross publicado en La Lectura Dominical el 19 de enero de 1896 (Fig. 6). Se separa de otros grabados al mostrarle de frente, pero creemos

25 Según recogía el periódico de Tortosa La Verdad, (24 de julio de 1894).

26 Además de estos libros, que parecen obedecer a un mismo patrón, muy erudito y católicamente ortodoxo, y ser menos espontáneos de lo que se quiso dar a entender, se publicó un díptico titulado Himno de la Peregrinación Obrera Española a Roma, Barcelona, 16 de abril de 1894, con el poema "A Roma Obrers/ A Roma Obreros", de Jacinto Verdaguer. También se editaron unas Instrucciones Generales para los Peregrinos y un Título de Peregrino Obrero a Roma para cada miembro de la expedición. 


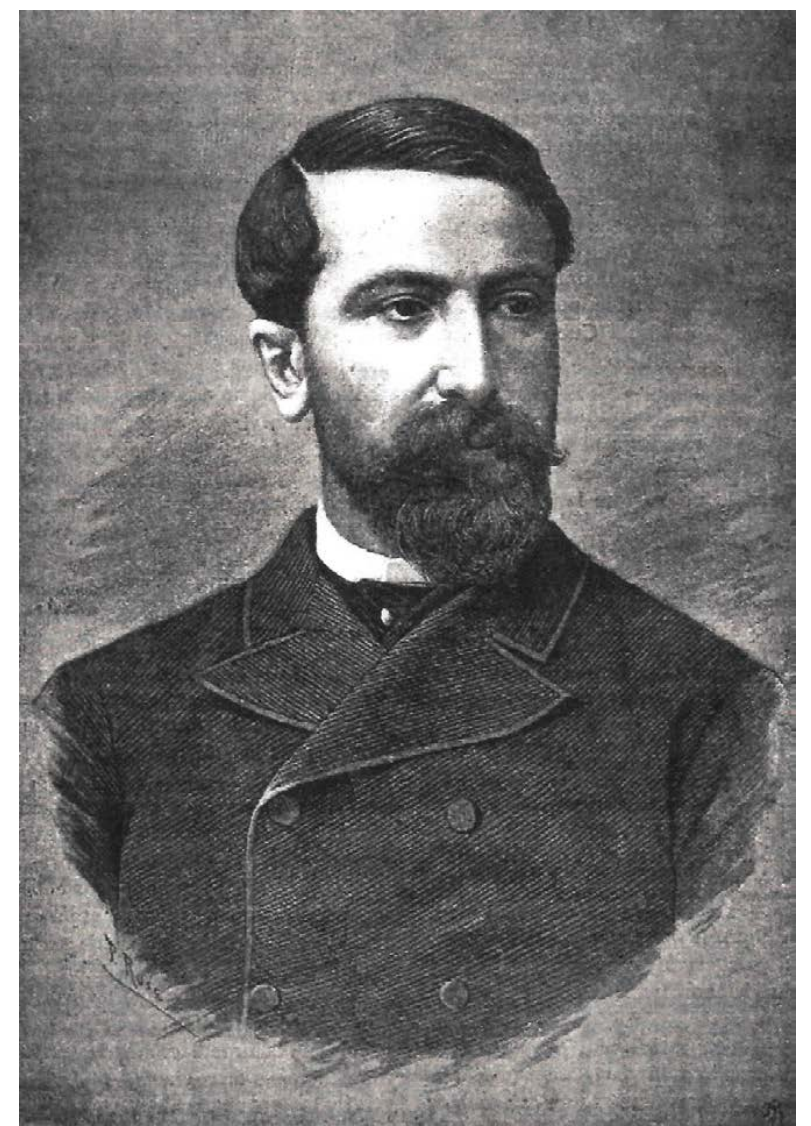

Fig. 6. Claudio López Bru. Paciano Ross. 1896. La Lectura Dominical

que deriva de la sesión fotográfica que dio lugar al fotograbado de Laporta publicado en 1890. Paciano Ross y Bosch fue pintor, dibujante e ilustrador, autor también del dibujo de un grabado de Antonio López. El comentario que acompañaba al grabado de Claudio, decía que éste llevaba una vida de trabajo, "de una monotonía fatigosa", y "de teatros y diversiones públicas o privadas no hay que hablar, pues el marqués jamás aparece por ellas". El joven marqués podía haber escogido el camino de dedicar "la enorme renta de su caudal a darse tono, a vivir en el más lujoso y confortable palacio con trenes deslumbradores y toda clase de opulencias". Pero optó, según esta publicación, por el camino del cristiano, dedicado al trabajo y negocios, y "sus negocios de caridad le embargan aún más tiempo que sus negocios mercantiles"; y además, la riqueza le impone deberes de "propaganda católica", de modo que "él es el nervio, el director material de todas las obras 


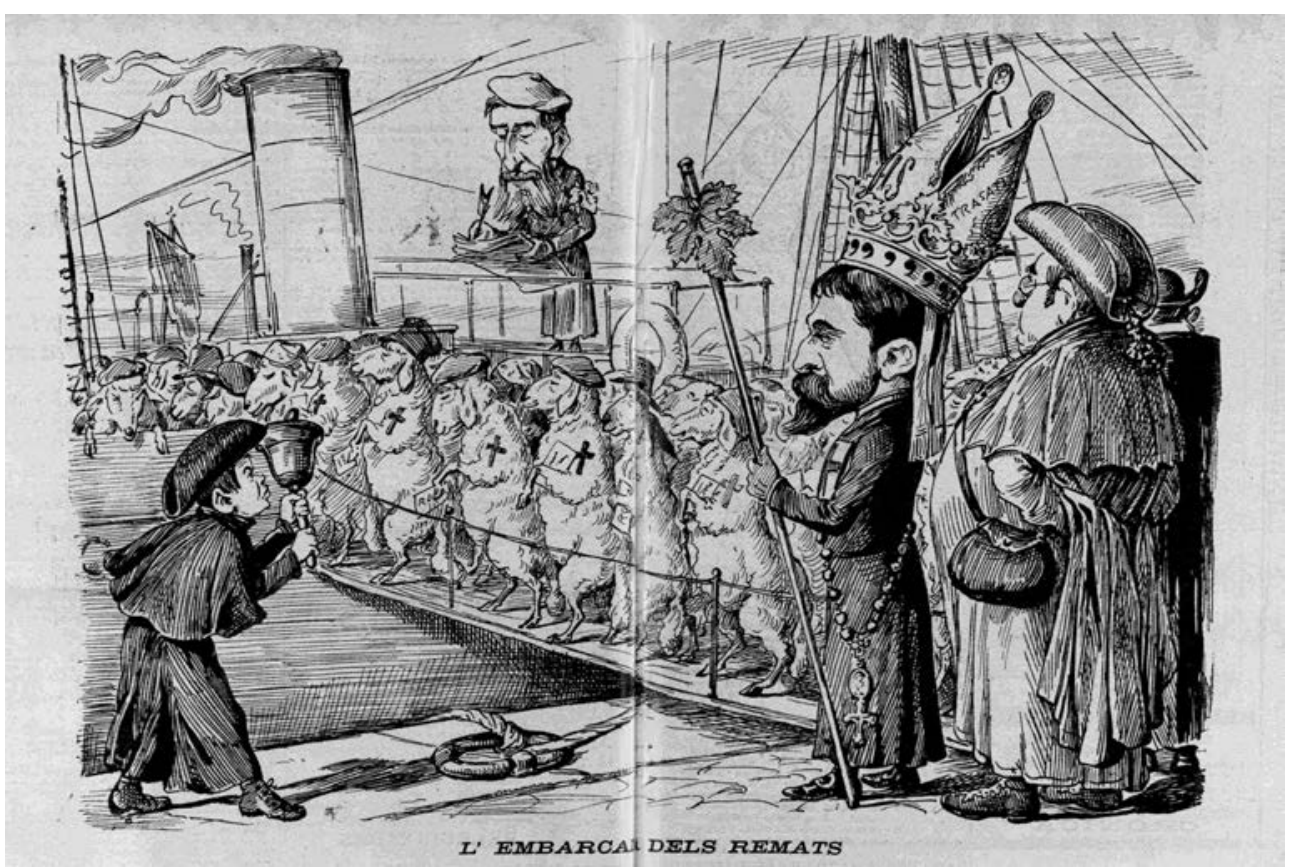

Fig. 7. Caricatura de la Peregrinación obrera a Roma. 1894. La Campana de Gracia

católicas que se han intentado en los últimos tiempos"27. Nada queda ya del Claudio López juvenil, es la vida de trabajo sin diversiones. El grabado fue reproducido después en la portada de La Ilustración Católica de España del 30 de junio de 1898 (II, 12).

\section{LA CARICATURA}

Frente a la imagen de empresa manifiesta en grabados que acompañaban textos elogiosos para Claudio López, surgió una serie de grabados críticos y satíricos con el marqués, con textos del mismo tono, especialmente en $\mathrm{La}$ Campana de Gracia, semanario republicano y anticlerical, y en alguna ocasión en la revista catalanista ;Cu-cut!. La mayoría de estas caricaturas utilizó la imagen de la cabeza de Claudio López del grabado de Laporta, que cobra así vida propia.

Así, el semanario barcelonés La Campana de Gracia hizo una burla de la Peregrinación a Roma, en el mismo año de la peregrinación, el 14 de abril de 1894 (pp. 4-5), con un Claudio López vestido de jesuita, con corona real y la mitra episcopal, controlando el embarque de peregrinos-ovejas (Fig. 7). Y de nuevo, el 5 de septiembre de 1896 el mismo semanario (p. 4) colocaba

27 La Lectura Dominical, Órgano del Apostolado de la Prensa, III, 107 (19 de enero de 1896), p. 1. 
la imagen de Claudio López en la popa de un vapor de la Compañía Trasatlántica como beneficiario de la distribución del empréstito, una operación para financiar la guerra de Cuba mediante la emisión de valores, es decir un préstamo de particulares al Estado, que tuvo mucha oposición en las Cortes $\mathrm{y}$ también en la prensa ${ }^{28}$.

El 12 de julio de 1902 se publicó otra caricatura de Claudio López en el mismo semanario, firmada por Robert, criticando los planes para reconstruir la Escuadra española tras el desastre del 98. En 1902 se aprobó la Ley Constitutiva de la Armada y se creó un organismo asesor, la Junta de Escuadra, poniendo las bases para la reconstrucción de la Escuadra española algunos años después. En la caricatura de Claudio López, se utilizaba una vez más la misma vista de perfil de grabados anteriores, con corona y sotana de jesuita. Al fondo figuraba un barco "religioso" con una iglesia como cabina, un púlpito para torre de vigía, el corazón de Jesús con la inscripción "Reinaré", estandarte, cruz, rosario, etc.; y debajo, la inscripción "Si es el marqués de Comillas el qui se'n ha de cuydá, aquí tenen el modelo que pels barcos servirá".

Otra caricatura más, inspirada en la misma imagen del marqués, se publicó en La Campana de Gràcia el 9 de abril de 1904 (p. 1) con motivo de la visita del rey a Barcelona el 6 de abril de 1904. Alfonso XIII entró ese día a caballo por el Paseo de Gracia, y el recibimiento constituyó un éxito, aunque Maura, promotor de la visita, resultó apuñalado. Claudio López, que figura arriba a la izquierda sobre el arco que mandó construir a sus expensas, tuvo gran protagonismo en la organización de la visita real, que formaría parte de un plan ideado por Maura para relanzar la figura del rey por España. Y ante la posibilidad de que esta visita a Barcelona fuera un fracaso o tuviera peligrosos incidentes,

“don Claudio respondió con épica. Reclutó 'miles de hombres', los dividió en grupos a cuyo frente puso amigos y parientes, tomó con ellos el contorno de la estación ferroviaria adonde llegaría el rey, supervisó en persona que no quedara 'hueco por donde pudiera colarse ningún peligro' y no contento con todo ello, habría seguido al propio líder populista Alejandro Lerroux 'sin perderlo de vista hasta dejarlo bien alejado" ${ }^{\prime 29}$.

De nuevo apareció una caricatura de Claudio López, esta vez junto a Antonio Maura, en La Campana de Gràcia el 22 de mayo de 1909, hablando sobre la Escuadra. Tras el desastre del 98, que destruyó gran parte de la Escuadra española, en 1908 se elaboró un Plan de reforma de la Armada, que dio lugar a un concurso para la construcción de numerosas unidades de la

28 HERNÁNDEZ SANDOICA, Elena y MANCEBO, María Fernanda, “El empréstito de 1896 y la política financiera en la guerra de Cuba", Cuadernos de historia moderna y contemporánea 1 (1980), pp. 141-170.

29 FAES DÍAZ, Enrique, Claudio López Bru..., p. 178. 
Escuadra. El resultado de este concurso se publicó el 14 de abril de 1909 en favor de la Sociedad Española de Construcción Naval, entre cuyos socios se hallaba la Compañía Trasatlántica. Hubo acalorados debates en el Congreso, disturbios en las calles y una denuncia por prevaricación ${ }^{30}$, pero el Plan fue aprobado en el Congreso. En el grabado se hallan Claudio López, Antonio Maura y el ministro de Gobernación Juan de la Cierva, bajo el título "Després dels escándols parlamentaris sobre la esquadra", y con estas palabras: "Maura: - Senyor marqués, no podém queixarnos. Cert que ab aquestas saragatas, s'han enfonzat una pila de cosas, però lo principal, ja ho veu s'ha salvat".

La caricatura publicada en La Campana de Gràcia el 9 de mayo de 1914 (p. 4), en la que figuran Eduardo Dato y Claudio López aplastados por un barco, hacía referencia a la Huelga general marítima, que afectó a la marina mercante española entre el 6 y el 22 de mayo de 1914, con diversas reivindicaciones, especialmente la de la creación de un Montepío Marítimo Nacional, reivindicación que se terminó aceptando, aunque con una promesa que pronto cayó en el olvido.

Otra caricatura más de Claudio López fue publicada en La Campana de Gràcia el 12 de agosto de 1916, en relación a la Procesión del Corpus. Ésta tenía una larga historia en Barcelona, como se encargó de recordar Antonio Aymar y Puig, autor del libro Memorias inéditas que pueden servir para demostrar el origen y la antigüedad e ilustrar la historia de la procesión del Corpus Christi en la Ciudad de Barcelona, Barcelona, Tipografía Católica, 1900. En 1896 hubo un atentado contra la procesión, de resultas de lo cual al año siguiente fueron fusiladas cinco personas. Claudio López, vestido de pieles y tirando de un perro o cordero de juguete con gorra marinera, porta en la caricatura un estandarte con la inscripción "Compañía Trasatlántica". En la misma página, la publicación se hacía eco irónicamente del regalo por parte del marqués de Comillas de un coche al nuevo obispo de Barcelona.

Otra revista que publicó caricaturas de Claudio López fue ;Cu-Cut! en la que el 7 de abril de 1904 aparecieron dos. Por una parte, una se refería a la visita real a Barcelona el día 6 de abril, y en relación con las obras del arco de triunfo mandado construir por Claudio López junto al palacio de la Diputación de Barcelona, donde se criticó que Claudio López hubiera solicitado licencia eclesiástica para poder trabajar en día festivo tan señalado como el Jueves Santo. La imagen del marqués sigue siendo la misma, la del grabado de $1892^{31}$. Y en el mismo número de la revista ;Cu-Cut! se publicó

30 ÁLVAREZ LAITA, Francisco Javier, "Implicaciones industriales del plan de Escuadra Maura-Ferrándiz", en Plan Ferrándiz. Poder Naval y Poder Marítimo, XXXVII Jornadas de Historia Marítima, Cuadernos monográficos del Instituto de Historia y Cultura Naval 57, Madrid, 2008, pp. 65-86.

31 ¡Cu-Cut!, 3, 119 (7 de abril de 1904), p. 218. 


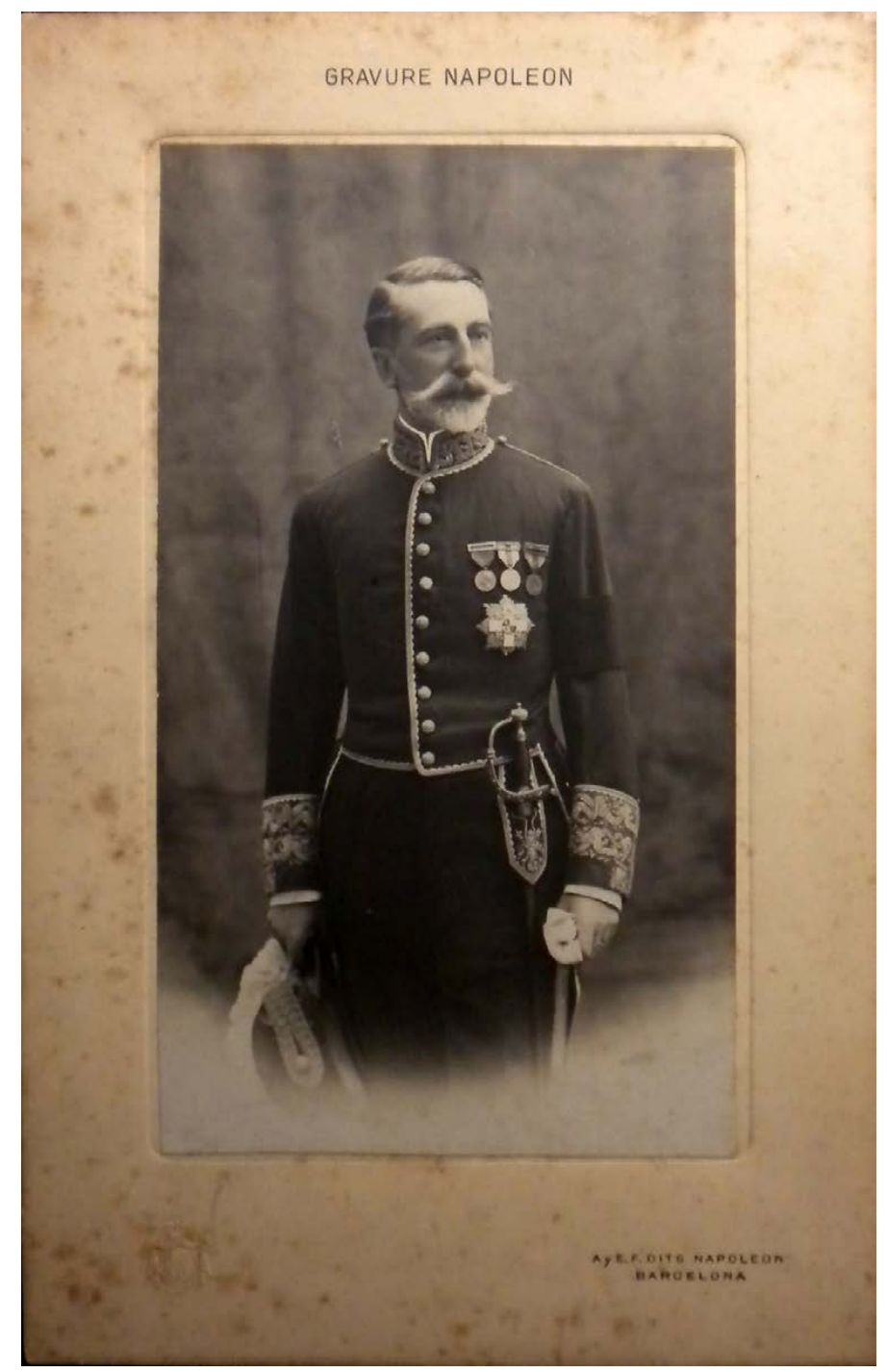

Fig. 8. Claudio López Bru con uniforme de Gentilhombre de Cámara. A. y E. F. dits Napoleón. Barcelona. H. 1904. Biblioteca del Palacio Real. Madrid

la "Parodia de la Llibertat illuminant el mon", con una "moneda illuminant Barcelona", en donde Claudio López aparece irónicamente como una "Estatua de la libertad". Es posible que, además de la evidente crítica del poder del dinero y del marqués, contenga una alusión a las luminarias del palacio Moja de Barcelona, muy llamativas cuando había determinados actos, como la llegada del rey. Aquí se utiliza una imagen frontal del marqués, que figura coronado, distinta a las anteriores. 


\section{LA ÉPOCA DE LOS UNIFORMES}

La tradición aristocrática española mantenía el uso de los uniformes para ceremonias públicas y privadas, lo que se acentuaba en torno a la Corte. Claudio López, al contrario que su padre, aparece ahora luciendo estos uniformes, exigidos por la etiqueta, y las condecoraciones toman un inusitado protagonismo.

Uno de los uniformes utilizados por Claudio López fue el de Gentilhombre de Cámara (Fig. 8), con el cual fue fotografiado hacia 1904². Constantino Bayle pone en boca de la Infanta Paz estas palabras:

"Cuando recién casada fui con mi marido a Barcelona y pasamos unos días inolvidables en su casa, me dijo mi hermano Alfonso: Yo no sé cómo demostrar a Comillas y a su cuñado Güell mi agradecimiento; si les doy una gran cruz, me la devuelven. Te voy a dar a ti dos llaves de Gentilhombre para ellos. Si les explicas que son las llaves de mi casa para que puedan entrar sin pedir audiencia, y se las das tú, las aceptarán, y así sucedió" ${ }^{33}$.

El decreto de su nombramiento como Gentilhombre de Cámara con ejercicio y servidumbre data del 23 de enero de $1884^{34}$. Unos meses antes, el 6 de julio de 1883, El Correo de Cantabria ${ }^{35}$ publicaba que se había mandado expedir carta de sucesión en el título de Marqués, con Grandeza, para Claudio López.

Claudio usó el uniforme de Gentilhombre de Cámara en la ceremonia celebrada en Palacio el 14 de mayo de 1889 para cubrirse ante la Reina varios Grandes de España, entre ellos él, "con uniforme de gentil hombre: padrino, el duque de Almodóvar del Río" ${ }^{36}$. Pero más tarde, el 2 de enero de 1892 Claudio escribía a su madre diciéndole: "Vengo de estrenar el uniforme de gala que me regalaste, en la recepción celebrada con motivo de los días del Rey" $^{\prime 37}$. No sabemos a qué uniforme se refiere en este caso.

La fotografía de Claudio López como Gentilhombre fue tomada por la casa fotográfica barcelonesa "Napoleón", fundada en 1851 por Antonio Fer-

32 Claudio López con uniforme de Gentilhombre Grande de España. Fotografía de "A. y E. F. dits NAPOLEON. BARCELONA". "GRAVURE NAPOLEON", Biblioteca del Palacio Real. Madrid. Fondo Paz (Infanta Paz) FOT/974. Sin fecha, h. 1904.

33 BAYLE, Constantino, El segundo marqués de Comillas..., pp. 69-70.

34 Archivo General de Palacio (AGP) C. 2. 641/44. Citado por FAES DÍAZ, Enrique, Claudio López Bru..., 2009.

35 El Correo de Cantabria, II, 151 (3 de julio de 1883), p. 3.

36 La Palma 27758, 15 de mayo de 1889, p. 2. La descripción de la ceremonia en Diario de Barcelona, (14 de mayo de 1889), pp. 6059-6060. Miguel de Asúa, en su biografía de Claudio López, de 1926, menciona extrañamente el "discurso de cobertura ante los Reyes, como Grande de España" del 12 de mayo de 1894.

37 BAYLE, Constantino, El segundo marqués de Comillas..., p. 93. 


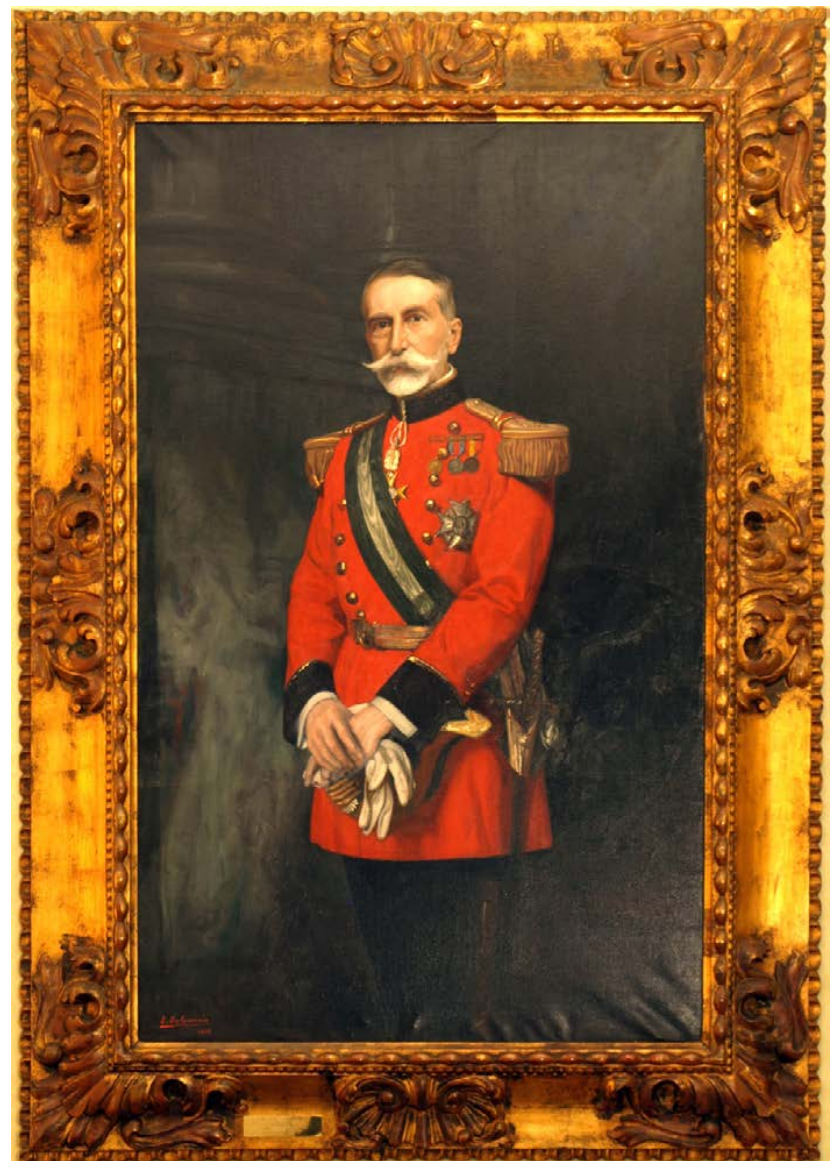

Fig. 9. Claudio López Bru con uniforme de la Orden Pontificia de la Espuela de Oro. Elías Salaverría. 1917. Universidad Pontificia Comillas (Madrid)

nández Soriano y Anaïs Napoleón. En esta casa fotográfica se retrataron las principales autoridades barcelonesas, e incluso sirvieron a la Casa Real, siendo nombrado Antonio fotógrafo de Cámara por Alfonso XII en 1875. El negocio fue continuado por sus hijos Emilio, Napoleón Francisco y Napoleón Fernando. La compañía firmaba sus trabajos bajo distintos nombres: "M. Fernando y Anaïs Napoleón”, “Fernando", "Fernando Napoleón fotógrafo", “Casa Mr. Napoleón", "A. y E. dits Napoleón" (a partir de 1867) o "A. y E. F. dits Napoleón", como aquí figura, señalando probablemente los nombres de Anaïs y sus hijos Emilio y Francisco Napoleón ${ }^{38}$.

En la fotografía, Claudio López lleva uniforme de Gentilhombre Grande de España con ejercicio y servidumbre, con frac azul de cuello vuelto de

38 GARCÍA FELGUERA, María de los Santos, "Anaïs Tiffon, Antonio Fernández y la compañía fotográfica 'Napoleón'”, Locvs Amoenvs, 8 (2005-2006), pp. 307-335. 
terciopelo y botonadura dorada, sombrero bicornio, guantes y espadín, con tres condecoraciones y la Gran Cruz de la Orden del Mérito Militar. Ésta es una cruz blanca, con corona real en el brazo superior; escudo contracuartelado de castillos y leones, granada en punta y escusón con las tres flores de lis. Las medallas son la de la Mayoría de Edad o de la Proclamación de Alfonso XIII (a la izquierda), la de la Regencia de María Cristina (centro) y la de Montserrat (a la derecha), esta última impuesta en 1904. En la mano derecha, junto con el sombrero, lleva el distintivo de la Llave dorada sobre lazo de seda roja con flecos de oro y la cifra del rey. En el brazo izquierdo lleva brazalete negro, suponemos que en señal de luto ${ }^{39}$. Tal vez la fotografía fue dedicada a la infanta Paz, que había promovido su nombramiento como Gentilhombre y como, al parecer, figura en su reverso, aunque la enmarcación actual impide observarlo.

La imagen más conocida de Claudio López es la del retrato pintado por Elías Salaverría (1883-1952) en 1917, hoy en la Universidad Pontificia Comillas (Madrid), y originalmente en el Salón de Actos de la Universidad en Comillas (Cantabria) ${ }^{40}$ (Fig. 9).

En el Diario de Valencia del 15 de julio de 1917 se decía que, en el contexto de las celebraciones por las bodas de plata del Seminario Pontificio de Comillas, "el público admiró el nuevo retrato del marqués de Comillas, hecho por el artista Salaverría" ${ }^{41}$. A estas celebraciones asistieron el Nuncio Francesco Ragonesi, los obispos de Santander, Valladolid y León, el infante Felipe, su esposa e hijos, numerosos aristócratas y jesuitas, e incluyó el traslado, el día 13, de los restos del Padre Tomás Gómez, fundador del Seminario, hasta la capilla de San Antonio de la iglesia del Seminario; y también se bendijo la estatua de la Virgen, "Stella Maris" que coronaba el edificio.

Escribe Constantino Bayle, a propósito de Claudio López y el Seminario, que

“Dios y ayuda costó al Rector del Seminario lograr que consintiera se le sacase un retrato (visto que no se hallaba por ninguna parte cuadro suyo) para el salón de actos, y sólo cedió ante la instancia de que en ello iba la honra de los Directores, a quienes justamente se culparía de ingratitud, si no colocasen un recuerdo perenne del que a todo el mundo constaba haber sido el fundador; tres semanas tardó en contestar a la carta en que se rebatía su negativa con

39 Claudio López utilizaba la banda negra de Baviera cuando estaba de guardia en palacio con el príncipe don Fernando María de Baviera y Borbón (1884-1958), infante de España y príncipe de Baviera, hijo de Luis Fernando de Baviera y de María de la Paz y Borbón. Pero no creemos que el brazalete sustituya a la "banda negra".

40 Consta que todavía estaba allí en 1925. CANCIO, Jesús, "La Universidad Pontificia de Comillas", en La Esfera, XII, 587 (4 de abril de 1925), pp. 25-26.

41 Diario de Valencia, VII, 2281 (15 de julio de 1917), p. 3. En similares términos lo repetía el Diario de Cádiz, IX, 3047 (15 de julio de 1917), p. 2. 
aquel argumento: 'todo ese tiempo he necesitado para resolverme a lo que tanto me cuesta [...] Pero yo suplico a usted considere todavía si es necesario ese sacrificio que de mí pide; pues yo abrigaba la ilusión de haber hecho ese poco que he hecho por el Seminario, sin que quedara memoria de mí"42.

La historia la sigue Giorgio Papàsogli:

“En el vigésimo quinto aniversario del seminario de Comillas, en 1917, el rector quiere poner en el salón de actos un retrato del marqués pintado por un buen artista. Busca alguna imagen del marqués, pintura o fotografía, que pueda servir de modelo, $y$, cosa extraña, no se encuentra ninguna que sirva para ese fin. Así pues, el rector se ve obligado a escribir al marqués para que se deje fotografiar. Su primera carta no tiene respuesta; una segunda tiene como contestación estas palabras de santo: 'Me ilusionará haber hecho lo poco que he hecho por el Seminario de Comillas sin que quede memoria de mí'. El rector insiste y hace ver al marqués que la gloria misma de la obra, es decir, la gloria de Dios, exige de él este sacrificio, y ante estas razones del rector don Claudio se aviene a posar para el gran pintor Salaberría"43.

Él mismo dijo en esta ocasión que conseguir su venia para ser retratado en pintura era "tarea tan difícil como la conquista de la India"44.

La colocación del retrato de Claudio López Bru en el Aula Magna o Salón de Actos del Seminario cambiaba la decoración pictórica de este espacio. En 1893 (según una crónica del 24 de agosto ${ }^{45}$ ) presidían este salón, en el centro, los retratos de Pío IX y León XIII, a cuyos pontificados correspondía el principio y el final de la fundación del Seminario. A un lado, y a continuación, estaba el retrato del Papa del momento, Pío X, proclamado el 12 de junio de 1893, un retrato "menos perfecto que los anteriores", como hecho a toda prisa; y le seguían los del ya difunto arzobispo de Burgos Manuel Gómez Salazar (fallecido el 14 de junio de ese año) y del Padre jesuita Francisco Rábago y Noriega, confesor real, por cuya intervención se había conseguido la erección del obispado de Santander en 1754, y situado aquí probablemente por su intervención en el Concordato de 1753; y a continuación "algunos cuadros religiosos" ${ }^{\prime 4}$. En el lado opuesto se hallaban los retratos de tres car-

42 BAYLE, Constantino, El segundo marqués de Comillas..., pp. 325-326.

43 PAPÀSOGLI, Giorgio, El marqués de Comillas..., p. 90.

44 Citado por FAES DÍAZ, Enrique, Claudio López Bru..., p. 333.

45 La Atalaya, I, 233 (24 de agosto de 1893), p. 1.

46 En 1932 se cita en el Aula Magna la existencia de una fotografía de Pío XI, "tres retratos al óleo grandes, uno de ellos firmado por Elías Salaverría y los otros dos sin firmar, y otro cuadro de mayor tamaño que representa la 'Apoteosis de Sto. Tomás'", figurando a ambos lados de la puerta de acceso dos retratos grandes al óleo, sin firmar, de León XIII y Pío IX. AHUPC, leg. H-157. 19-II-1932. La "Apoteosis de Santo Tomás" era una copia de gran tamaño del cuadro firmado y fechado por Zurbarán en 1631 para el convento dominico de Santo Tomás de Sevilla, hoy en el Museo de Bellas Artes de dicha ciudad. En Comillas mostraba la orientación tomista de los estudios del Seminario. 
denales jesuitas, Juan de Lugo y Quiroga (1583-1660), Francisco de Toledo Herrera (1532-1596) y Roberto Bellarmino (1542-1621); les seguía el retrato del arzobispo de Lima y natural de Comillas, Juan Domingo de la Reguera; el de Saturnino Fernández de Castro (1827-1886) ${ }^{47}$, natural de Comillas y quien, como arzobispo de Burgos, asistió a la colocación de la primera piedra del Seminario en 1883; y por último, se menciona que estaba el retrato de su padre "Ignacio", probablemente su tío, el naviero Ignacio Fernández de Castro. En cambio, los retratos de Antonio López y de su hermano Claudio se hallaban situados en el llamado "salón de recibo". El Salón de Actos fue concebido por tanto con una iconografía estrictamente religiosa y no tenían cabida aquí los retratos de la familia López, sólo colocados en ese lugar en 1917, siendo prueba de ello una fotografía que muestra los retratos de Antonio y Claudio López en el estrado del Salón de Actos del Seminario Pontificio de Comillas, en las Fiestas Jubilares de $1917^{48}$.

El pintor elegido para el retrato de Claudio López fue Elías Salaverría (Lezo, Guipúzcoa, 1883-Madrid, 1952) ${ }^{49}$, quien no pintó el retrato del natural, como sugiere el texto de Papàsogli, sino que lo hizo sobre una fotografía de Kaulak enviada por Claudio López a instancias del rector del Seminario ${ }^{50}$. Aunque se ha relacionado esta fotografía con el hecho de que Claudio López fuera nombrado Comisario Regio de la Exposición de Industrias Eléctricas, de Barcelona, el 23 de junio de $1914^{51}$ (pero la exposición no se celebró hasta 1917), no parece lógico pensar que se tomara para esta exposición vestido con un uniforme de connotaciones religiosas. Es posible que haya habido una confusión dado que el retrato fotográfico de Claudio López por Kaulak (muy recortado) fue publicado en La Esfera en mayo de 1917, ilustrando un

47 Una biografía de Saturnino Fernández de Castro en La Verdad, Tortosa (29 de abril de 1886), pp. 2-3.

48 ABAD, Camilo María. S.J., El Seminario Pontificio de Comillas. Historia de su fundación y primeros años (1881-1925), Madrid, Tipografía Católica, de Alberto Fontana, 1928, p. 160.

49 Estudió en la Escuela de Artes y Oficios de San Sebastián de 1894 a 1897, año en el que marcha a la Academia de Bellas Artes de San Fernando hasta 1904, teniendo por maestros a Alejandro Ferrant y Moreno Carbonero; después tiene por maestro a Luis Menéndez Pidal, hasta 1908. En 1909 va a París y alcanza el éxito en 1912 al obtener la medalla de oro de la Exposición Nacional de Bellas Artes, en 1913 en la Exposición Internacional de Bellas Artes de Munich (La procesión del Corpus) y en 1916 en la Exposición Internacional de Panamá. En 1944 ingresa en la Academia de Bellas Artes de San Fernando con un discurso sobre "El cuadro de Historia". Ejecutó pintura de historia, costumbrismo, retrato y pintura decorativa.

50 Retrato fotográfico de Claudio López. ABC. El negativo original de gelatino-bromuro sobre placa de vidrio en la Biblioteca Nacional KAULAK/7/44/19: Marqués de Comillas 51899. Consta en los archivos de ABC (2693x1829) fechada de manera aproximativa como de 1914, y bajo el título "El marqués de Comillas, que ha sido nombrado Comisario regio en la exposición de industrias eléctricas de Barcelona". Referencia en ABC: 6194806.

51 La Construcción Moderna, XV, 12 (30 de junio de 1917), p. 1. 
artículo de Mariano Rubió y Bellvé titulado “La próxima exposición de Barcelona", y en donde figura como comisario de dicha exposición. De la misma sesión en el estudio de Kaulak es la fotografía del marqués que figura en el álbum El Seminario y Universidad Pontificia de Comillas en el XXV aniversario de su fundación. 1892. Álbum conmemorativo. 1917 (Barcelona, Sociedad General de Publicaciones, 1918).

El retrato Claudio López en el salón de actos del Seminario Pontificio se hallaba en 1917 junto a los retratos del Papa y de su padre Antonio López. Esto explicaría la elección del uniforme de la Orden pontificia de la Espuela de Oro que Claudio luce en este retrato, y que no tiene sentido en relación con la exposición de industrias eléctricas de Barcelona. Como uniforme de una Orden pontificia resulta adecuado para lo que se había denominado inicialmente como "Seminario Pontificio", y que se erigió canónicamente como Seminario Pontificio de San Antonio, de Comillas, por decreto papal del 29 de marzo de 1904. Pero el hecho de que Claudio López ostente las insignias de la orden pontificia de la Espuela de Oro (concedida en 1909) y no figure en la fotografía con el Toisón de Oro, concedido el 22 de enero de 1914, nos hace sospechar que la fotografía es anterior a esta última fecha, y quizá más próxima a 1909.

La fotografía de Claudio López fue publicada en Mundo Gráfico el 22 de abril de 1925 como obra del "ilustre artista Sr. Kaulak", es decir, el conocido fotógrafo Antonio Cánovas del Castillo y Vallejo (1862-1933). Sin embargo, esta misma fotografía fue publicada, en formato ovalado, en el libro de Miguel Gascón Luz sin sombra. El marqués de Comillas, Comillas, 1925; y después, en El Previsor, algo recortada, en febrero de 1927, y en ambos casos firmada por el fotógrafo Alfonso Ciorán (1896-1933) ${ }^{52}$, que firma también algunas de las fotografías publicadas por el padre jesuita Camilo María Abad en su libro El Seminario de Comillas, de $1928^{53}$.

Según escribió Gabriel Ricardo España en Mercurio, revista comercial hispano-americana, y se reprodujo en 1924 en el libro dedicado al monumento a Claudio López en Cádiz, Claudio López "jamás dio un retrato. Los contadísimos publicados lo fueron por sorpresa: indiscreciones de Kaulak o de Franzen" ${ }^{54}$. El retrato de Christian Franzen (1864-1923) no lo conocemos, y el de Kaulak no es un retrato por sorpresa sino una pose de estudio. En la fotografía de Kaulak y en el retrato de Salaverría, Claudio López lleva uni-

52 El Previsor. Revista mensual de economía práctica. Órgano de la "Asociación Hispano-Americana propagadora de la Previsión y del Ahorro", XLIII, 50 (febrero de 1927).

53 ABAD, Camilo María, S.J., El Seminario Pontificio..., p. 89.

54 Monumento al Marqués de Comillas. Memoria descriptiva del Monumento y de los trabajos realizados por la Comisión Organizadora. Cádiz, Rodríguez de Silva, 1924, p. 12. 
forme de la Orden de la Espuela de Oro o Milicia Áurea, con guerrera roja con dos hileras de botones de cantones dorados; cuello y puños de terciopelo negro fileteados con hilo de oro; hombreras de charreteras con los emblemas de la Orden bordados y flecos de hilo de oro; y pantalones negros con franjas de oro. El cinturón es de oro y gules, con hebilla de la empresa de la Orden. Las botas, no visibles, deberían ser negras con espuela de oro. En la mano sostiene el sombrero bicornio con la divisa papal y cinta cuatribarrada. La espada es de ceñir, con empuñadura en oro y gules. Lleva la Insignia de la Orden de la Espuela de Oro, que pende al cuello con un collar, apenas visto, con eslabones que alternan el monograma de Cristo " $\mathrm{XP}$ "; cruz maltesa dorada con una pequeña espuela pendiente del brazo inferior, sobrepuesta de un centro esmaltado de blanco, resaltado del monograma M (María), acompañado de la fecha 1905 y la divisa "Pius X Restitutur". Esta insignia pende de un trofeo de oro y cinta de color rojo, con franjas en los bordes de blanco. Claudio López había sido nombrado caballero de la Orden Pontificia de la Espuela de Oro por la ayuda que prestó en 1908 a los habitantes de Messina (Sicilia, Italia) tras el terremoto que asoló la ciudad. El Papa le comunicó la concesión de las insignias de la Orden en carta remitida en los primeros días de marzo de $1909^{55}$.

En la guerrera lleva la Gran Cruz de Carlos III, de plata, de cuatro brazos iguales de ocho puntas rematadas por semiesferas lisas, simétricos dos a dos, con centro de esmalte azul. En cada antebrazo, flor de lis de plata. En el exergo, óvalo con la Inmaculada Concepción y la cifra de Carlos III con el lema "VIRTVTI ET MERITO". Asociada a esta Gran Cruz está la banda cruzada de seda de color azul celeste y franja central blanca. El 24 de julio de 1908 Claudio López había recibido la credencial de la Gran Cruz de la Real y Distinguida Orden de Carlos III:

"Queriendo dar una señalada prueba de Mi Real aprecio a Don Claudio López Bru, Marqués de Comillas; y de acuerdo con el parecer de Mi Consejo de Ministros, Vengo en agraciarle con la Gran Cruz de la Real y distinguida Orden de Carlos Tercero en la vacante por defunción de Don Carlos Navarro Rodrigo. Dado en San Sebastián a veinticuatro de Julio de mil novecientos ocho. (Firmado) Alfonso" 56 .

55 La Correspondencia de Valencia, XXXII, 10682 (6 de marzo de 1909), p. 3, refiere que el Papa "ha dirigido un autógrafo al marqués de Comillas... concediéndole las insignias de oro de la orden de la Espuela". Casi un mes después, el 1 de abril de 1909 lo recoge El Monte Carmelo, X, 210, p. 42, indicando que el marqués había recibido "las insignias de la Orden de la Milicia Dorada, vulgarmente conocida con el título de la Espuela de Oro". En el ámbito republicano levantó crítica, y así El Pueblo, diario republicano de Valencia, XVI, 6093 (9 de marzo de 1909), p. 1, criticaba que se hubiera concedido esta distinción a quien -según ellos- le habían "regalado" 10 millones de pesetas y el monopolio de los transportes marítimos.

56 Archivo Histórico Nacional (en adelante AHN), Exteriores C_224. El Poble Català, 5, 0896 
La Orden de Carlos III era muy estimada y en el siglo XVIII no se permitía que fuera compatible con ninguna otra, nacional o extranjera, incluso la del Toisón de Oro, que sin embargo también recibió Claudio López.

Porta además Claudio López sobre el pecho tres medallas con cintas y pasadores, medallas que fueron diseñadas por el medallista, pintor y grabador Bartolomé Maura y Montaner (Palma de Mallorca, 1844 - Madrid, 1926), director artístico de la Fábrica Nacional de Moneda y Timbre y grabador jefe del Banco de España. En el centro, la medalla de la Regencia de María Cristina, creada el 16 de mayo de 1903, representándose en el anverso las cabezas superpuestas de María Cristina, al fondo, y de Alfonso XIII, con la inscripción “M. CHRIS. HISP. REG. CATH. PIETATE AC PRVDENTIA EXIMIAE MATRI DILECTAE". En el reverso esta medalla lleva el escudo real con el Toisón de Oro, las fechas "1885-1902" y la leyenda "FORTITVDO ET DECOR INDVMENTVM EIVS". A su derecha, con cinta roja, la Medalla de la Mayoría de Edad o de la Proclamación de Alfonso XIII, que llevaría en el anverso la inscripción "ALPHONSVS XIII D.G. HISP. REX" y en el reverso "17 MAII 1902". A su izquierda, la Medalla de Montserrat, creada en 1904 por Alfonso XIII con motivo de la proclamación de la Virgen de Montserrat como patrona de los Somatenes de Cataluña. La medalla lleva en el anverso el busto de Alfonso XIII de uniforme de gala, con el Toisón de Oro, con las inscripciones "ALFONSO XIII" y "10 ABRIL 1904". En el reverso, relieve con la adoración de la Virgen de Montserrat. El 10 de abril de ese año, el rey pasó revista en Montserrat a los efectivos del Somatén (entonces unos 18000 hombres) tras haber puesto la primera piedra del monumento a los héroes del Bruch y proclamarse que los somatenes quedaban constituidos como agentes de la autoridad; y el marqués de Comillas figuró como uno de los miembros de la comisión organizadora de la fiesta ${ }^{57}$. El Somatén tenía una larga historia en Cataluña, pero resultaron decisivos su oficialización en 1875 como institución permanente, y el nuevo Reglamento aprobado el 30 de junio de 1890, vigente hasta la Dictadura de Primo de Rivera. En 1902 el marqués de Comillas era uno de los once miembros que formaban parte de la Comisión organizadora del Somatén en Cataluña, que en ese año ya tuvo un papel enfrentado a las luchas revolucionarias, papel que iría aumentando progresivamente, en especial a partir de $1917^{58}$.

El cuadro de Salaverría fue alterado, probablemente cuando se colocó en el Salón de Actos del Seminario. A la izquierda del cuadro se añadieron unas

(29 de julio de 1908), p. 3, menciona el Decreto de la concesión.

57 La Vanguardia, XXIII, 10037 (11 de abril de 1904).

58 GONZÁLEZ CALLEJA, Eduardo y REY REGUILLO, Fernando del, La defensa armada contra la revolución. Una historia de las guardias cívicas en la España del siglo XX, Madrid, CSIC, 1995. 
pinceladas, que imitan humo, para tapar el fondo decorado de arquitectura y mobiliario lujoso, donde todavía hoy se puede ver una cabeza de elefante decorativa; y a la derecha, apenas se ve un sillón con un manto, quizá con el escudo pontificio. El fondo sobre el que destaca la figura no es por tanto un negro continuo, y quizá se pensó en 1917 que la decoración introducida por Salaverría no era acorde con la colocación del cuadro.

La elección del pintor, Elías Salaverría, venía marcada por los antecedentes biográficos y artísticos de éste. Acababa de triunfar, no sin algunas críticas, con un retrato de San Ignacio de Loyola para el Salón de retratos de la Diputación de Guipúzcoa, cuadro que, situado en el Museo Victoria Eugenia de San Sebastián, ya era admirado por el obispo-prior de las órdenes militares el 9 de agosto de 1916, y dos días después por la reina Cristina. La revista La Esfera reprodujo el cuadro el 9 de septiembre y el 14 de octubre (detalle de la cabeza) y le rodeó de elogios. Al año siguiente, 1917, el cuadro fue presentado a la Exposición Nacional de Bellas Artes (inaugurada el 28 de mayo), y entonces el crítico Luis León escribió negativamente el día de la inauguración por haber querido presentar "una figura simbólica", huyendo de los retratos "auténticos" que existían de San Ignacio, de modo que Salaverría "o tiene un falso concepto del misticismo, o no ha sabido expresar lo que pretendía". Pero al día siguiente otro crítico, anónimo, decía en El Noroeste (de La Coruña) que era un cuadro "admirable",

"pintado con verdadera fuerza de sugestión y en el que sobre el fondo sombrío y estrecho del valle del Loyola la figura del santo fundador se alza, sin más puntos luminosos sobre la negrura de capa y sotana, que las manos cruzadas y la calva cabeza inclinada en actitud de meditación, en la que las pupilas desaparecen bajo el arco de las cejas pronunciadas" 59 .

El día 5 de junio, en La Correspondencia de España, J. García Mercadal ya decía que "sin disputa la obra cumbre del presente concurso" era este cuadro de San Ignacio, y hacía una larga digresión sobre el arte cristiano de la época:

"Hay quien defiende que nuestros pintores actuales no es posible lleguen a pintar de modo acertado figuras de santos, porque los tiempos presentes no son los más a propósito para que nadie sienta en su alma el sentimiento de la santidad. Esto sería tanto como proclamar que para pintar a un santo sólo pudiera hacerlo otro santo.

Lo cierto es que el San Ignacio de Salaverría es un cuadro que impresiona a cuantos se detienen a contemplarlo, y que cuantos pasan a su lado quedan como clavados por la fuerza con que la figura subyuga; esto demuestra, bien a las claras, que todo ello no se ha conseguido exclusivamente con un gran acierto de ejecución, en la que destaca poderosamente la simplicidad del procedimiento, sino que si llegó a lograrse fue porque su autor hubo de estudiar, antes de pintar la figura, el alma del personaje y el reflejo espiritual que debía

59 M., “Barnizando”, El Noroeste, XXII, 10053 (29 de mayo de 1917), p. 1. 
despedir la figura para llegar a impresionar a quienes habían de contemplarla.

Es cuadro el de 'San Ignacio' llamado a levantar grandes discusiones, pero éstas siempre versarán sobre si el pintor entendió o no el carácter del evocado; unos y otros, los que afirmen y los que nieguen, se juntarán unánimes para proclamar unánimes las excelencias del artista, considerando a este cuadro como el más acertado de cuantos se exponen en el actual certamen del Retiro".

Mercadal alababa sobre todo la cabeza del santo, plena de luz, y cuya frente era "campo de profundas y elevadas meditaciones". Tres días después, el 8 de junio, le contestaba con una crítica negativa Francisco Martín Caballero en La Correspondencia de Valencia, diciendo que el cuadro "no impresiona ni mueve a fervor", faltándole "unción de santidad", aunque la figura estuviera bien pintada; y el fondo de paisaje era "absurdo". Nuevamente la revista La Esfera salió en defensa del cuadro de Salaverría un mes después, el 7 de julio, donde Silvio Lago escribió que

"es un criterio monjil y murillesco el que se ha querido aplicar a este cuadro admirable de potencialidad enérgica y de severo realismo. Es así, con toda su hosquedad, con todo su enigmático hieratismo, como debe concebirse al fundador. Pocos cuadros modernos alcanzan tan alta permanencia espiritual como este San Ignacio de Salaverría".

Qué duda cabe que los jesuitas estaban enterados de la apasionada polémica del cuadro de San Ignacio, que figuraba en la Exposición Nacional de Bellas Artes en el mismo año en que le encargaban pintar el retrato del marqués de Comillas, ya terminado el 15 de julio de 1917, de modo que sería pintado en plena polémica por el cuadro de San Ignacio.

De otro lado, la biografía de Salaverría y el resto de su obra anterior encajaban con lo que los jesuitas querían. Salaverría era de origen humilde, campesino y marinero; era el artista-monaguillo, alguien que había comenzado a dibujar siendo monaguillo en el Santuario del Santo Cristo de Lezo (Guipúzcoa), y a quien el arquitecto Francisco de Cubas, marqués de Cubas, tomó bajo su protección, llevándole a la Escuela de Artes y Oficios de San Sebastián con 12 años, y a la muerte del marqués, siguió siendo ayudado por sus hijas, la marquesa de Aldama y la condesa de Arcentales. Protegido por el empresario Nicolás María de Urgoiti, es llevado a Madrid, donde fue discípulo de Luis Menéndez Pidal. Sus primeras obras fueron caracterizadas como "luminismo sorollista", estilo que luego abandonó. En el verano de 1903 pintó en las sierras limítrofes de Asturias y León y después comenzó a concurrir a las Exposiciones Nacionales de Bellas Artes: en la de 1904 obtuvo mención honorífica; y en las de 1906 y 1908 obtuvo terceras medallas, lo mismo que en la Exposición Universal de Buenos Aires de 1910. Después se presentó con un cuadro a unas oposiciones para obtener beca en Roma, pero no lo logró. Su gran triunfo llegó con el cuadro "La procesión del Corpus en Lezo", que aunque fuera atacado minoritariamente por su carácter religioso 
o por falta de sentimiento u originalidad, recibió numerosos elogios y una primera medalla en la Nacional de 1912. Causó asombro el monaguillo-pintor, casi desconocido: "Salaverría, aunque haya sido monaguillo, aunque sea vascongado, ha pintado el mejor lienzo del certamen". El cuadro de "La procesión del Corpus de Lezo" fue muy reproducido en las revistas, especialmente en La Esfera. Se alababa en él el paisaje y las figuras, sobre todo el sentimiento, y especialmente las cabezas, magistrales "por su expresión, por la firmeza de su dibujo y colorido, por la fuerza de vida que en ella palpita", algo que ya adelanta lo que se vería en el retrato de Claudio López, con una vigorosa cabeza muy expresiva. En el mismo año de 1912 la diputación de Guipúzcoa le concedió una pensión anual de 5000 pesetas, por dos años prorrogables, con la cual marchó a París.

La Compañía de Jesús sintonizaría fácilmente con él. El crítico Emilio Pisón escribió el 24 de octubre de 1924 en La Libertad que Salaverría era "un místico hechizado de visiones claustrales. Sus obras son, en su mayoría, vírgenes famosas, santos ilustres [...] Salaverría es, pues, el pintor de los santos". Los cuadros de Salaverría no dejaban indiferentes, especialmente las expresiones de los rostros. El retrato de Claudio López podría parecer que es una simple traslación mecánica de la fotografía de Kaulak, pero no es así. El cuadro se afirma rabiosamente y de hecho se hace inolvidable para quien lo contempla, constituyendo la imagen "definitiva" del marqués. La expresión del rostro es muy intensa, no un mero posado, y aunque esto ya estuviera en la fotografía, en el cuadro se hace mucho más intenso. Y el colorido del uniforme y medallas contrasta brutalmente con el fondo oscuro del cuadro. El personaje de la fotografía puede dejar indiferente, pero el del cuadro no. Silvio Lago escribió en 1916 a propósito de la exposición de cuadros de Salaverría en San Sebastián el año anterior, que la mayoría eran "retratos interpretados con señorial distinción, con refinada elegancia, en una sabia sobriedad de gamas, reveladora del sutil temperamento de Salaverría" ${ }^{\prime 60}$.

La imagen de Claudio López con el vistoso uniforme de color rojo de la Orden pontificia de la Espuela de Oro, impresionó vivamente. José Del Río Sáinz, Pick, identificaba a Claudio López con la época de la Reina Madre, la Regencia de María Cristina, en una necrológica publicada en La Atalaya el 19 de abril de 1925, y en la misma página en que se publicaba la fotografía de Kaulak, decía:

"Nosotros guardamos de este marqués que acaba de morir, como una estampa pintoresca, la visión policromada y áurea de su cuerpo severo, forrado en el uniforme de áureos bordados, con que le vimos una vez en Comillas, no hace muchos años, en la boda de una marquesita allegada suya. Verdadera

60 LAGO, Silvio, "Artistas contemporáneos. Elías Salaverría", La Esfera, III, 124 (13 de mayo de 1916), p. 28. 
estampa cortesana y palatina era la de este marqués de barba ya nevada por los años y de rostro melancólico y bondadoso" ${ }^{61}$.

Llama la atención que Claudio López se presentara con vistosos uniformes llenos de condecoraciones. Decía Constantino Bayle respecto a las medallas, que "no es lucirlas el llevarlas lo menos posible", y con eso justificaba su uso por Claudio López. Giorgio Papàsogli escribió en $1984^{62}$ que "las placas y las bandas las lleva solamente cuando en las tarjetas de invitación que le llegan del Palacio Real se indica que hay que llevar 'condecoraciones"'. En la botadura del vapor Bustamante el 4 de mayo de 1904 en el Astillero de la Trasatlántica, a la cual no pudo acudir el rey pero se le esperaba, Claudio López llegó "luciendo uniforme de grande de España" y "también ostentaba el Marqués de Comillas la Gran Cruz del Mérito Naval"63. Usaba por tanto los uniformes y condecoraciones según la ocasión y la etiqueta lo exigía. En este caso se esperaba la visita del rey, que no se produjo hasta el día 6, de ahí que usara el uniforme de "Grande de España", y con la condecoración adecuada al acto marítimo, la Gran Cruz del Mérito Naval, regalada además por los gaditanos.

Según la propia declaración de Claudio López en 1914, en ese año poseía las siguientes distinciones: Marqués de Comillas, Grande de España de $1^{\underline{a}}$ clase, Gentilhombre de Cámara de S.M. con ejercicio y servidumbre, Gran Cruz del Mérito Naval, Cruz de Beneficencia de 1a clase, Gran Cruz del Mérito Militar, Caballero Gran Cruz de San Gregorio el Magno, Caballero de la Orden de Cristo, Gran Banda de $1^{a}$ clase de la Humanitaria Orden Liberiana de Redención Africana, Gran Caballero de la Orden de la Legión de Honor, Gran Cruz de la Orden del Mérito Real de San Miguel de Baviera, Gran Cruz de Carlos III y Caballero de la Milicia Áurea o Espuela de Oro ${ }^{64}$.

A ello se añadió el nombramiento como Caballero de la Insigne Orden de Toisón de Oro, el 22 de enero de 1914, que no figura en el retrato, lo que hace sospechar que la fotografía original date de antes de esta fecha: "Queriendo dar un relevante y distinguido testimonio de Mi Real aprecio a don Claudio López y Bru, Marqués de Comillas, Vengo en nombrarle Caballero de la Insigne Orden del Toisón de Oro" ${ }^{65}$.

Miguel Gascón, en su biografía de Claudio López refiere su reacción al recibir la noticia de la concesión del Toisón de Oro: “¿tú te figuras cuántos

61 La Atalaya, XXXIII, 11844 (19 de abril de 1925), p. 1.

62 PAPÀSOGLI, Giorgio, El marqués de Comillas..., p. 90.

63 La Correspondencia de Cádiz, XXIX, 8549 (5 de mayo de 1904), p. 2.

64 AHN, Exteriores C_8 (2). Concesión del Toisón de Oro a Claudio López. Se publicó en la Gaceta el 22 de enero de 1914.

65 AHN, Exteriores C_8(2). Concesión del Toisón de Oro a Claudio López. 
me han de poner ahora mala cara, cuando me vean por la calle?" ${ }^{66}$. Claudio López nombró por padrino a Andrés Avelino Salavert y Arteaga, Marqués de la Torrecilla, y el Toisón de Oro le fue impuesto el 29 de enero de 1914. El 31 de marzo de 1925, pocos días antes de su fallecimiento, Claudio López recibió la Gran Cruz de Isabel la Católica ${ }^{67}$. El padre de Claudio, Antonio López y López, marqués de Comillas y Grande de España. también había sido distinguido por el rey, pero no exhibía la condecoración que se le concedió, la "Encomienda de número de la Real orden Americana de Isabel la Católica", el 17 de junio de 1860, por la ayuda prestada por sus vapores en la guerra de África ${ }^{68}$.

Claudio López poseía dos condecoraciones militares, que no figuran en el retrato de Salaverría. La Gran Cruz de la Orden del Mérito Militar le fue concedida por Real Decreto publicado en La Gaceta el 12 de junio de $1890^{69}$. Además, en enero de 1896 se publicó el Real Decreto concediéndole la Gran Cruz de la Orden Militar del Mérito $\mathrm{Naval}^{70}$. En 1897 en el periódico El Guadalete se publicaba que el Casino Gaditano le regaló al marqués un álbum con las insignias de la Cruz del Mérito Militar ${ }^{71}$. Pensamos que debe ser una confusión, y se trata de la citada condecoración de la Orden Militar del Mérito Naval.

Entre 1894 y 1896 Claudio López recibió numerosos homenajes y distinciones civiles, publicándose en 1894 varios libros sobre la Peregrinación Obrera a Roma, que él había organizado; también un Álbum de agradecimiento de 1001 obreros de la Trasatlántica; el "opúsculo" a él dedicado sobre el Cabo Machichaco; etc. La Diputación provincial de Santander había solicitado en 1893 el título de Hijo adoptivo de la provincia para el marqués de Comillas y que se colocara su retrato en el salón de sesiones de la Diputación; y en abril de 1895 ya se le había entregado la credencial de Hijo adoptivo ${ }^{72}$. Además, en 1896 Claudio López recibió el título de Hijo Adoptivo de La Habana, y "el señor marqués de Comillas se mostró muy agradecido con tal deferencia, que dijo no merecer; pues, en su concepto, todo lo que ha hecho y está dispuesto a hacer por la causa de España, lo considera como un deber

66 GASCÓN, Miguel, Luz sin sombra..., p. 48.

67 AHN, Exteriores C_307.

68 AHN, Exteriores C_242 (2).

69 El Guadalete, XXXVI, 10510 (14 de junio de 1890), p. 2. Crónica Meridional, XXXI 9030 (15 de junio de 1890), p. 2. Correo de Tortosa (13 de junio de 1890), p. 1.

70 Diario de Burgos, VI 1484 (17 de enero de 1896), p. 3. La Correspondencia de España, XLVII, 13859 (16 de enero de 1896), p. 2.

71 El Guadalete, XLIII, 12741 (21 de agosto de 1897), p. 3.

72 La Atalaya, III, 835 (27 de abril de 1895), p. 2. 
que en esta ocasión cumplen todos los buenos españoles"73.

A finales de 1893 se pensó en conceder una distinción al marqués de Comillas por su ayuda a la ciudad de Santander tras la explosión del vapor Cabo Machichaco el 3 de noviembre de 1893, de trágicas consecuencias; pero Claudio López rechazó la iniciativa de su nombramiento como "duque de Santander" ${ }^{\prime 74}$. A la acostumbrada alusión a su modestia y humildad se añadía que ya era Grande de España, que había preferido que su esposa recibiera el lazo rojo y la cifra de brillantes como Dama de la Reina, además de que al no tener descendencia, el título ducal se perdería ${ }^{75}$. Como alternativa, el Gobierno Civil de Santander abrió a principios de 1894 un expediente con la solicitud de ingreso en la Orden civil de Beneficencia para Claudio López, la cual recibió el informe favorable del Consejo de Estado en el mes de julio ${ }^{76}$.

La actuación de Claudio López y la Compañía Trasatlántica en la ayuda prestada a la ciudad de Santander en relación con la explosión del vapor Cabo Machichaco, que causó 590 muertos, fue objeto de elogios, incluyendo un discurso pronunciado por el diputado Emilio Alvear en el Congreso de Diputados en las sesiones 13 y 16 de abril de $1894^{77}$. Es sorprendente la autoridad que ejerció Claudio López en Santander, que había quedado con el Ayuntamiento descabezado por la explosión, siendo capaz de configurar prácticamente un nuevo Ayuntamiento. Pero la Compañía Trasatlántica también pagó un alto precio en vidas, puesto que el vapor auxiliar $n^{\circ} 5$ de la Compañía colaboraba en la extinción del incendio del Cabo Machichaco cuando explotaron las 51 toneladas de dinamita que éste transportaba, devastando a la tripulación del auxiliar, lo que será recordado con una placa en el vapor Alfonso XIII (vapor gemelo del Cabo Machichaco, de la Compañía Ybarra), ejecutada por el escultor sevillano Antonio Susillo ${ }^{78}$. Por otra parte, Belisario Santocildes Palazuelos publicó un opúsculo de dieciséis páginas titulado El 3 de noviembre de 1893, Santander, Imprenta y encuadernación de L. Blanchard, 1894, sobre la catástrofe del Cabo Machichaco, dedicado al marqués de Comillas, donde se comparaba a Claudio López con el “Ángel de la Caridad" socorriendo a las víctimas y a los huérfanos ${ }^{79}$.

73 La Atalaya, IV, 1366 (17 de octubre de 1896), p. 2.

74 La Atalaya, I, 345 (15 de diciembre de 1893), p. 2.

75 La Atalaya, I, 354 (24 de diciembre de 1893), p. 2.

76 La Atalaya, II, 389 (29 de enero de 1894), p. 3. El Correo de Cantabria, XIII (14 de febrero de 1894), p. 3. El Correo de Cantabria, XIII, 31 (12 de marzo de 1894), p. 2. El bien público, XXIII, 6352 (21 de julio de 1894), p. 3.

77 La Atalaya, II, 476 (27 de abril de 1894), p. 7.

78 El Aviso, XXIII, 115 (29 de septiembre de 1894), p. 3.

79 Comentario sobre este opúsculo en La Atalaya (9 de diciembre de 1894), p. 2. 


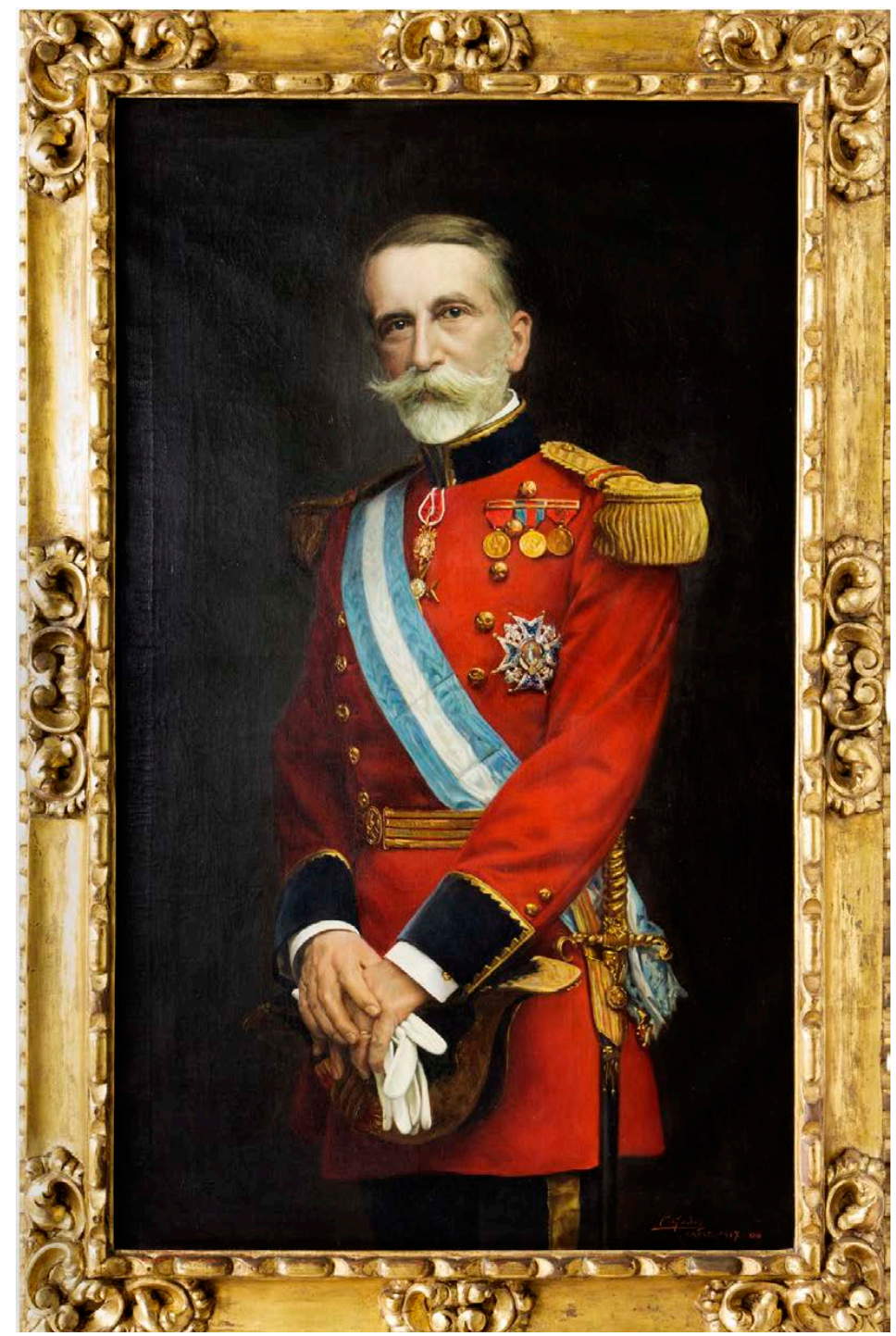

Fig. 10. Claudio López Bru. Federico Godoy Castro. 1917. Museo Marítimo de Barcelona

La aceptación de medallas y honores fue constante, pero Constantino Bayle justificaba el uso de las medallas por parte de Claudio López diciendo que las llevaba lo menos posible y sólo si se lo exigía la etiqueta:

"A la par de la pobreza, cristianamente amada, va la modestia: y por ella D. Claudio fue reconocido como la modestia personificada: no es frase convencional: es opinión de cuantos se le acercaron; ni se requería la intimidad para echarla de ver. Lo buscaron todos los honores que un vanidoso pudo apetecer, las condecoraciones más preciadas del Papa y del Rey: el jamás pretendió ni 
una sola y rechazó muchas: la del Toisón se la comunicaron por telégrafo, y le causó verdadero disgusto, sin mengua del debido agradecimiento a la regia merced. Y ni las pretendió ni las lucía, porque no es lucirlas el llevarlas lo menos posible, cuando la etiqueta o la cortesanía lo demandaban: la banda negra de Baviera sólo la ponía si le tocaba la guardia en palacio con el príncipe D. Fernando; la del Mérito Naval, que le regalaron los gaditanos, la arrinconó por lujosa (había costado 27000 pesetas); ya que alguna había que llevar, prefería la de Carlos III, por ser de la Inmaculada y haberla heredado de su padre, y la del Mérito Militar, por juzgarla mejor ganada" ${ }^{\prime 0}$.

El retrato de Salaverría dio lugar a diversas versiones, con algunas diferencias. Un retrato de Claudio López prácticamente igual al de Salaverría y pintado en el mismo año de 1917 es el ejecutado por Federico Godoy Castro (Cádiz, 1869-Sevilla, 1939) ${ }^{81}$, del Museo Marítimo de Barcelona (Fig. 10). Godoy, en sus retratos, procura resaltar el rostro y sitúa la figura sobre fondo negro para resaltar el colorido de aquélla, como sucede en este caso, a diferencia del cuadro de Salaverría que originalmente ostentaba figuras decorativas. Tal vez al propio Godoy se deba la misma versión del retrato de Claudio López, pero de medio cuerpo, con destino a la sede de la Compañía Trasatlántica en Cádiz (Palacio de Gargollo).

El retrato de Claudio López por Fernando Álvarez de Sotomayor, del Museo MAS de Santander ${ }^{82}$, probablemente pintado en 1925, se hallaba situado originalmente en el trasatlántico Marqués de Comillas, botado en el año 1926, en el rellano de la escalera que comunicaba el "hall" con el salón de música ${ }^{83}$. En el comedor, continuando con el homenaje al marqués, había reposteros de seda con las armas de la Casa de Comillas, en medio de una decoración regionalista que aludía a las casas solariegas del norte de España.

80 BAYLE, Constantino, El segundo marqués de Comillas..., p. 324.

81 Claudio López Bru, por Federico Godoy Castro. Museo Marítimo de Barcelona. Firmado en el ángulo inferior derecho: F. Godoy. Cádiz. 1917. Federico Godoy Castro se formó desde 1878 en la Escuela Especial de Bellas Artes de Cádiz y después en la Academia de Bellas Artes de San Fernando entre 1893 y 1897, asentándose en Madrid. Regresó a Cádiz en 1902 como profesor de la Escuela de Bellas Artes de dicha ciudad y al año siguiente ingresó como Académico en la de Bellas Artes de San Fernando. Permaneció en Cádiz hasta que en 1929 pasa a ser profesor de la Escuela de Bellas Artes de Sevilla. Sobre Federico Godoy, Federico Godoy pintor de Cádiz, catálogo de la exposición, Caja San Fernando, 1999. BLOND GODOY, María África, "Federico Godoy, su vida y su obra", Anales de la Universidad de Murcia, 53-54 (1967), pp. 323-358.

82 Retrato de Claudio López por Fernando Álvarez de Sotomayor, ¿1925? Museo MAS de Santander, donación de la familia Pereda Pérez, aceptada por el Ayuntamiento de Santander el 10 de noviembre de 2008. Medidas: 185,5 x 140 cm., registro 1613. En La Ilustración Española y Americana se glosaba su figura y se trazaba su biografía en un artículo publicado el 30 de diciembre de 1918.

83 GONZÁLEZ ECHEGARAY, Rafael, Los tres Comillas, semblanza biográfica de tres buques gemelos, Madrid, Estades Artes Gráficas, 1962, p. 18. 
En 1961 el vapor sufrió un devastador incendio en El Ferrol, que terminó con el barco, pero afortunadamente el cuadro había sido retirado meses antes. Reproduce la figura de los retratos de Salaverría y Godoy, pero lo inserta en un marco arquitectónico y un paisaje marítimo, además de añadirle un manto y otros detalles nuevos. Así, viste el uniforme de caballero de la orden de la Espuela de Oro, pero del cuello pende el Toisón de Oro, que le había sido concedido el 22 de enero de 1914, y no la insignia de la Espuela de Oro.

Como en los retratos anteriores, Claudio López lleva la banda y la Gran Cruz de la Orden de Carlos III, pero ahora añade una placa medio tapada por la banda, que parece la placa de la Gran Cruz de la Suprema Orden de Cristo, con la cruz (no visible) inserta en un círculo y rodeada de rayos de plata. Las medallas son las mismas de los retratos anteriores, es decir, de izquierda a derecha, las de la Mayoría de Edad de Alfonso XIII (de oro); la Regencia de María Cristina (de plata); y la Medalla del Somatén (de oro). El manto blanco sobre la silla, incluido por Sotomayor, es el de la Orden Suprema de Cristo, que le había sido concedida por el Papa en $1894^{84}$. Era una antigua orden instituida por Juan XII el 14 de marzo de 1319, restaurada por el papa en 1905, y cuyo símbolo es la Cruz latina patada. El Breve de Pío X de la restauración indicaba "que ninguna otra le fuese superior en dignidad y que sobresaliese de todas las demás en grandeza y esplendor".

Claudio López reunió las más importantes condecoraciones pontificias, como ninguno había tenido hasta entonces. Miguel Gascón en su biografía de Claudio López de 1925 le define como "modelo de caballero cristiano" y dice que "sólo el Marqués de Comillas, entre los católicos de todo el mundo, poseía las dos más altas condecoraciones pontificias: la Orden Suprema de Cristo y la de la Milicia Áurea" ${ }^{85}$. Claudio López fue además Caballero de la Orden Pontificia de San Gregorio Magno, con cuyo uniforme acudió a la Consagración de España al Sagrado Corazón de Jesús en el Cerro de los Ángeles el 30 de mayo de 1919.

El cuadro de Sotomayor fue comentado monográficamente en un artículo de Federico Leal ("El marqués de Comillas por Álvarez de Sotomayor") incluido en El Universo el 15 de abril de 1927, describiendo "la figura marmórea, heroica e impasible del almirante creador de las nuevas flotas de la paz, junto con el mílite esforzado de la armada de Cristo", comparándole con el retrato de Andrea Doria. Después, el cuadro fue objeto de un poema escrito por el jesuita Ramón Cué y publicado en 1942, y que comienza así: “¿Qué bien retrató el pintor / al Marqués / mi señor...! / Así es, / cual lo vio

84 Según reseña el diario ABC, 47, 14969 (26 de febrero de 1954), p. 1, que comenta la concesión de esta distinción a Francisco Franco.

85 GASCÓN, Miguel, Luz sin sombra..., p. 8. 
Sotomayor" ${ }^{\prime 86}$. Hay otra versión de este cuadro, más moderna, en el Banco de Crédito Industrial de Madrid, donde figura con el añadido de una inscripción en la parte superior, con una extraña cronología: "EX. S. D. CLAUDIO LOPEZ BRU MARQUES DE COMILLAS / 1853 - 1957 I PRESIDENTE DEL BANCO DE CREDITO INDUSTRIAL".

El cuadro de Sotomayor fue reproducido en el libro de Camilo María Abad, El Seminario Pontificio de Comillas, de 1928, con la firma de Claudio López al $\mathrm{pie}^{87}$. La reproducción fue realizada por la "Heliotipia de Kallmeyer y Gautier", de Madrid. Otto Kallmeyer Fessel se estableció en Madrid como fototipista en 1914, fundando "Gráficas Kallmeyer", y desarrolló una amplia carrera imprimiendo tarjetas postales, hasta su fallecimiento en 1968.

En el Palacio Moja de Barcelona hay además una versión, anónima y algo diferente, del retrato de Claudio López vistiendo el uniforme de la Orden de la Espuela de Oro y la capa de la Orden de Cristo, las dos distinciones pontificias, y con la banda de la orden de Carlos III.

La relación de Claudio López con el Papa quedó representada fielmente en un tríptico situado en el Palacio de Sobrellano en Comillas (Fig. 11). Como reacción a las implicaciones morales y religiosas del arte moderno de finales del siglo XIX -del realismo al modernismo y el simbolismo-, un grupo de artistas e intelectuales y amantes del arte, configuraron en 1893 en Barcelona una asociación artística católica, el "Círculo Artístico de San Lucas". El Círculo se sumó a la gran Peregrinación obrera a Roma en homenaje al Papa, una iniciativa impulsada por los obispos españoles y protagonizada por el marqués de Comillas. En 1894 el Círculo exponía el pendón portado por los socios en la Peregrinación, pendón que había sido diseñado por Enrique Sagnier y que tenía una representación de la Virgen de la Merced, por Dionisio Baixeras, orlada por Alejandro de Riquer y dorada por Oliva y de Martí8 ${ }^{\text {. }}$ Y el Círculo fue encargado de elaborar un tríptico en homenaje a Claudio López por su papel de impulsor de la Peregrinación, que fue considerada un éxito rotundo, y por ella el marqués de Comillas fue nombrado Caballero de Cristo por el Papa.

La sección central de la Junta Diocesana de la peregrinación a Roma del obispado de Barcelona se dirigió a las demás Juntas de España, tras obtener la aprobación y patrocinio de los cardenales de Sevilla y Valencia, así como la bendición del obispo de Barcelona, para abrir una suscripción que costeara "un recuerdo alegórico" como muestra de gratitud al marqués de Comillas,

86 CUÉ, Ramón S.J., Comillas. Itinerario-Lírico, Santander, Aldus, 1942.

87 ABAD, Camilo María, S.J.: El Seminario Pontificio..., entre pp. 176 y 177.

88 MARCHI, Maria Barbara, Cercle Artístic de San Lluch 1839-2009: historia d'una institució referent per a la cultura barcelonina, Tesis Doctoral, Dept. de Historia del Arte, Universitat de Barcelona, 2011. 


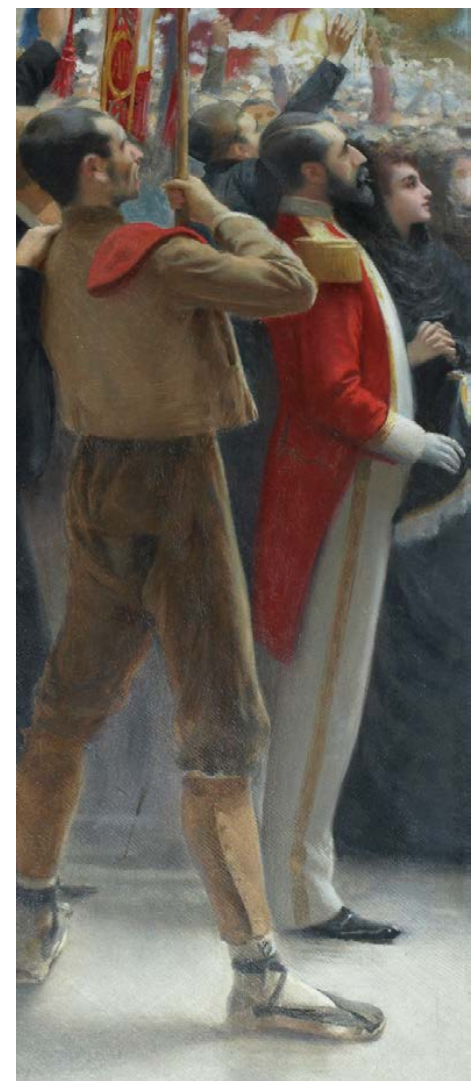

Fig. 11. Tríptico de la Peregrinación obrera a Roma, detalle. Antoni Utrillo. 1894-95.

Palacio de Sobrellano, Comillas

reconociendo que el éxito se debía a él. En la suscripción figurarían al frente los obispos y participarían los romeros y cuantos hubieran colaborado en la peregrinación. Este recuerdo alegórico es por tanto el tríptico que se encargaría al Círculo Artístico de San Lucas y que en diciembre de 1894 ya se estaba elaborando ${ }^{89}$. Se trata de un Tríptico de madera y bronce diseñado por Juan Martorell y dirigida por Enrique Sagnier Villavecchia, con pinturas de Antoni Utrillo (firmadas en 1895), y esculturas de José Llimona (San Diego de Cádiz, San Juan de Ávila, la Purísima Concepción y Santiago o San Jorge), con la intervención en la fundición de bronce de los talleres del decorador Joan Riera y Casanovas ("Joan Riera tallista y constructor") y del orfebre Federico Masriera. En febrero de 1896 la obra ya estaba terminada. Según El Noticiero, "figura el cuadro central el momento en que Su Santidad León XIII llevado en la silla gestatoria, rodeado de cardenales, obispos y altos dignatarios de

89 La Unión Católica, VIII, 2223 (10 de diciembre de 1894), p. 3. La crónica se repetía el 16 de diciembre en La Lectura dominical, p. 11. 
la corte pontificia, bendice a los peregrinos que apinándose artísticamente en los dos cuadros laterales, le aclaman entusiastas".

$Y$ en uno de los cuadros laterales, donde figuran peregrinos con sus estandartes, "se ve al Excmo. Marqués de Comillas con el uniforme de la Orden de Cristo en actitud noble y severa saludando al Pontífice resultando tal vez el más notable de los retratos que hemos mencionado" ${ }^{90}$.

El tríptico fue entregado el 12 de febrero de 1896 a Luisa Bru, madre de Claudio López, y a Eusebio Güell, comisionados para ello por el marqués ${ }^{91}$. Las pinturas recogen la peregrinación a Roma en 1894, bajo Pío X, patrocinada por Claudio López y organizada por el cardenal Cos y Macho, que llevaron a Roma a 20000 obreros (algunas fuentes hablan de 16000 y otras cifras) y 24 prelados. Por el lugar tan destacado que ocupa el tríptico en el palacio de Sobrellano, se comprende que la peregrinación fue considerada por Claudio López como uno de los mayores logros de su vida.

\section{La imagen civil de Claudio López}

Las biografías tradicionales de Claudio López han transmitido una imagen amable y serena del personaje, enérgico pero de suaves modales, como lo describen José Manuel Pérez Sarmiento y Gabriel Ricardo España en $1924^{92}$, y Constantino Bayle en $1928^{93}$. Esta imagen, que ciertamente es real, contrasta con el hombre de acción que también fue. Por ejemplo, en el mitin católico celebrado en Barcelona el 20 de enero de 1907, dirigido contra la Ley de Asociaciones, se produjeron incidentes, y "durante los desórdenes, el marqués de Comillas, al frente de un numeroso grupo de católicos, persiguió a los agresores que huían" ${ }^{94}$.

Claudio López tenía que hacer frente a la enfermedad. El doctor que le trataba en París, Jean Casimir Félix Guyon, uno de los más importantes urólogos de la época, en 1897 le aconsejaba reposo y él acudía a tomar los baños en el mes de junio en Panticosa ${ }^{95}$. La imposibilidad de tener descendencia debía ser entonces una de las principales preocupaciones de Claudio López, y además, quizá en relación con ello, padecía tuberculosis crónica, que ad-

90 Crónica reproducida en el semanario La barretina, V, 157 (14 de febrero de 1896), p. 2.

91 El Aralar, III, 602 (20 de febrero de 1896), p. 2.

92 Monumento al Marqués de Comillas. Memoria descriptiva del Monumento y de los trabajos realizados por la Comisión Organizadora. Cádiz, Rodríguez de Silva, 1924, pp. 8-9.

93 BAYLE, Constantino, El segundo marqués de Comillas..., p. 305.

94 La Correspondencia de España, LVIII, 17876 (21 de enero de 1907), p. 3.

95 El Bien Público, XXVI, 7206 (11 de junio de 1897), pp. 1-2. Para cumplir con las prescripciones de reposo y tomar las aguas balnearias, Claudio López disponía de una casa en Caldetas (Barcelona), que encargó construir en 1883 a José Oriol Mestres. 
quirió poco antes de cumplir los 30 años. Y en torno a 1900 dictó testamento, manifestando su "abatimiento físico y moral"

Un reducido grupo de fotografías dan cuenta de su aspecto físico y sus actividades sociales al tiempo que señalan su renuencia a ser fotografiado. Una fotografía improvisada de Claudio López junto a un jesuita delante del Seminario de Comillas y antes de una fotografía "oficial", obtenida en 1917, fue comentada por Camilo María Abad en 1928, señalando su natural resistencia a ser retratado a la vez que el trato cercano que mantenía con unos y otros:

"Una fotografía de los antiguos alumnos con los Marqueses se quería hacer, después de la Misa, en la gradería de entrada a la iglesia. Mientras se ultimaban los preparativos, el Marqués, con llaneza admirable, sentóse bajo los plátanos de la explanada, en lo primero que halló a mano, un cajón de embalar que por allí rodaba, sin que hubiera modo de hacerle cambiar de silla. Allí estuvo conversando muy familiar y expansivo con varios Padres, hasta que le entregaron el correo, que despachó en pocos minutos desde el improvisado gabinete. Cuando le indicaron que se iba a hacer la fotografía, después de resistirse un momento a formar en el grupo, como vio que se ponían el Sr. Nuncio y los Sres. Obispos, se resignó diciendo: ¡Vaya por Dios!"97.

Una fotografía publicada por Miguel Gascón en su libro Luz sin sombra. El marqués de Comillas, Comillas, 1925, puede datarse en 1917, pues figura de modo muy similar a la fotografía publicada por Camilo María Abad junto a un sacerdote delante del seminario de Comillas y datada en ese año. Es probable que la silueta del marqués esté recortada y en origen fuera una fotografía del natural en un exterior, lo que explicaría la presencia del abrigo. Cabe la duda de si se trata de un fragmento de la fotografía "oficial" delante del Seminario de Comillas en 1917, que comenta Camilo María Abad. Ignoramos quién fue el fotógrafo. Enrique Faes, en su biografía del marqués del año 2009, recoge que se decía de él que "cualquiera de sus amigos vestía mejor que él" y que "como buen patriota, usaba siempre género español", mientras otros refieren que compraba sus trajes "en Inglaterra y de la mejor calidad", vistiendo "a tono con su condición social" 98.

En la revista mensual Páginas Escolares, de Gijón, del 1 de julio de 1925, se publicaba, junto a la fotografía de perfil del marqués de Comillas, el artículo de Federico Tedeschini titulado "Singular elogio del Marqués de Comillas del Nuncio de Su Santidad, Mons. Tedeschini", en el que éste decía que Claudio López (fallecido el 18 de abril) "era un santo", un "alma canonizable"; y entre sus virtudes alababa que "él se ha rodeado y cercado de una va-

96 Citado por FAES DÍAZ, Enrique, Claudio López Bru,.., p. 339.

97 ABAD, Camilo María, S.J.: El Seminario Pontificio de Comillas..., p. 145.

98 FAES DÍAZ, Enrique, Claudio López Bru..., p. 337. 
lla defensora e impenetrable: el secreto". Habla Tedeschini "de su extremada humildad y de su absoluto retraimiento", y menciona

"recompensas que acaso el mundo no conozca, porque, según su costumbre, el Marqués las ocultaba, basta con citar la Orden Suprema de Cristo y la Orden, tan elevada, de la Milicia Aurea, las cuales sólo en el Marqués pienso hayan ido asociadas" 99 .

Sin duda se estaba pensando ya en la beatificación de Claudio López. El retrato de Claudio López pintado por Cristóbal Montserrat y Jorba ${ }^{100}$ en 1925 debe tratarse de un homenaje póstumo al fallecer el marqués, destinándose a ser colocado en la Compañía General de Tabacos de Filipinas. Se le representa de medio cuerpo, y figura con vestimenta de gala, con pajarita y camisa de cuello alto blanco. El rostro evidencia ya el paso de los años y el semblante parece cansado.

Claudio López Bru fue retratado también al óleo por José María Vidal-Quadras y Villavecchia (Barcelona, 1891-1977) ${ }^{101}$, en un cuadro que se conserva en el Palacio Moja de Barcelona, de chaqueta, abrigo al brazo y gorra marinera en la mano, sobre el fondo de una bandera al viento, y contexto náutico. Sabemos que hizo un retrato del marqués de Comillas hacia 1940, y si era éste sería un retrato póstumo (Claudio falleció en 1925), pero el citado encargo podría ser para un retrato del marqués en ese momento, Juan Antonio Güell y López. Claudio López, además de Presidente de la Compañía Trasatlántica, fue, por lo que a la mar se refiere y en su vida particular, propietario de un yate de regatas, el Ilet de 15 metros, y que en 1917 ya había vendido ${ }^{102}$.

99 Páginas Escolares, Gijón, XXII, 239 (1 de julio de 1925), pp. 121-125.

100 En la esquela del pintor Cristóbal Montserrat y Jorba, de 1935, éste figura como "Artista pintor. Congregante de la Purificación y San Francisco de Borja". Había nacido en Barcelona en 1869, pasando su infancia en Vilanova i la Geltrú. Fue discípulo de Luis Rigalt en la Escuela de Bellas Artes de Sant Jordi, en Barcelona (1881-83), y estudió también en Madrid, probablemente en escuela privada, y en París. Fue miembro del Real Círculo Artístico de Barcelona. Fue un retratista muy prestigioso, contándose entre sus retratados Alfonso XIII y María Cristina (1888) y en general la alta sociedad de Barcelona, y también, sorprendentemente, Mussolini y Hitler.

101 José María Vidal-Quadras y Villavecchia (Barcelona, 1891-1977), miembro de una familia de banqueros catalanes, de niño estudió en Austria y Suiza; después en la Escuela de Bellas Artes de Barcelona, viajando a continuación por Italia, Francia y Austria. Fue discípulo de Hugo von Habermann (Dillingen, 1849-Munich, 1929) en Munich y de Félix Mestres Borrell (1872-1933) en Barcelona. Expuso en 1914 por primera vez; en 1919 tuvo su primera exposición individual; y en 1920 participa en la Exposición Nacional de Bellas Artes. En 1927 contrajo matrimonio con Teresa Rosales Fernández de Castro, hija del que poco después sería director general de la Compañía General de Tabacos de Filipinas. Tras la guerra civil, durante la cual fue encarcelado, recibió numerosos encargos para retratar a la aristocracia barcelonesa, entre ellos uno del marqués de Comillas en 1940.

102 El Adelanto, Salamanca, XXXIII, 10155 (9 de julio de 1917). 
El cuadro parece reflejar un aspecto lúdico de la marina, pero también podría estar en relación con la Liga Marítima Española, a cuya Junta Central pertenecía Claudio López.

\section{LOS MONUMENTOS}

En la Alameda de Apodaca de Cádiz se alzó un monumento a Claudio López, segundo marqués de Comillas, obra del escultor catalán Antonio Parera, que fue inaugurado en 1922 (Fig. 12). La erección de un monumento dedicado a Claudio López en vida es un hecho muy sorprendente. La reacción que ello pudiera suscitar aconsejó rápidamente enmascararlo como un monumento de exaltación hispano-americana, y, consciente de la crítica que se le podría hacer, Claudio López se resistió al monumento y optó por no acudir a la inauguración.

El periódico de San Fernando (Cádiz) El Justiciero lanzó en 1908 la idea de un homenaje a Claudio López, Hijo Adoptivo de Cádiz, y, como señalaba el periódico Cádiz por dentro el 30 de octubre de ese año, "se desea levantar su estatua en sitio céntrico de Cádiz, como testimonio de perenne agradecimiento" ${ }^{103}$. En La Época, el 18 de octubre se decía que el monumento, que asociaría a Cádiz, San Fernando y Puerto Real, se alzaría en la plaza de San Francisco, frente a la iglesia del mismo nombre y preveía que "la idea no contará con el beneplácito del ilustre marqués, cuya modestia es bien conocida" ${ }^{104}$.

Diez años después, en 1918, el Cónsul de Colombia en Cádiz, José Manuel Pérez Sarmiento, retomó el tema, apoyado por la Real Academia Hispano-Americana de Cádiz y después por el Ayuntamiento de la ciudad. Se formó el 18 de agosto una Comisión Mixta de Concejales del Ayuntamiento y Académicos de la Hispano-Americana, bajo la presidencia del alcalde, abriéndose una suscripción, aunque Claudio López se opuso inicialmente al monumento escribiendo desde Comillas una carta al alcalde, Manuel García Noguerol, y al director de la Real Academia Hispano-Americana, Pelayo Quintero, el 29 de septiembre de $1918^{105}$. Argumentaba Claudio López que era "injustificada gratitud", pues la deuda que creían tener con él, ya la consideraba "saldada" con la muestra de "cariño", y el proyecto chocaba con sus "arraigadas convicciones" personales. Claudio López "sólo cedió ante el criterio de las autoridades eclesiásticas y del Rey"106.

103 Cádiz por dentro, I, 13 (30 de octubre de 1908), p. 1.

104 La Época, LX, 20827 (18 de octubre de 1908), p. 2.

105 El Cantábrico, XXIV, 9121 (11 de agosto de 1918), p. 3.

106 FERNÁNDEZ REGATILLO, Eduardo, Posiciones y artículos para el proceso..., p. 67. 


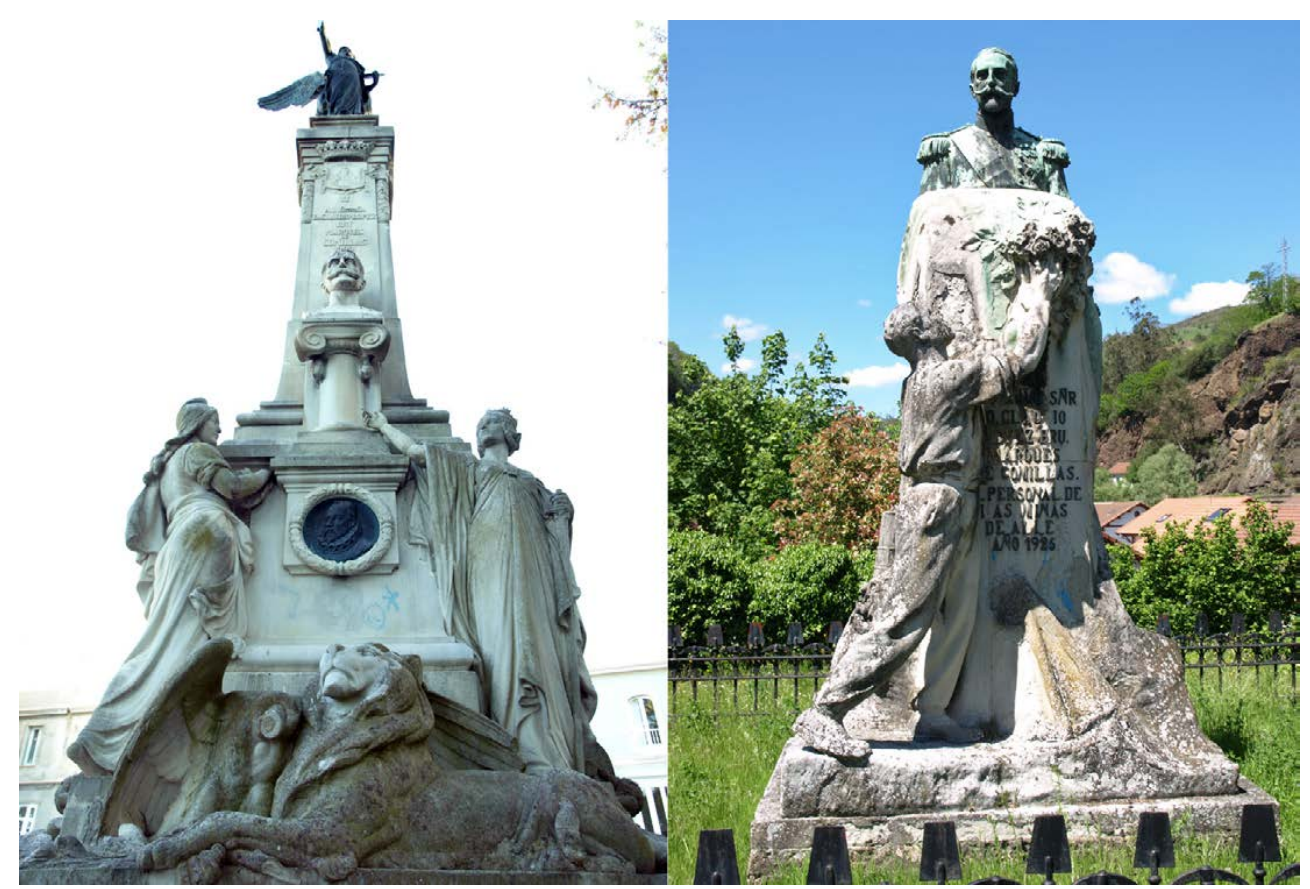

Fig. 12. Monumento a Claudio Lópezz. Antonio Parera. 1919-22. Cádiz

Fig. 13. Monumento a Claudio López. Alfredo Marinas. 1925. Bustiello (Asturias)

Lo que Pérez Sarmiento ${ }^{107}$ proponía era hacer un monumento a la entrada del muelle de Cádiz, que además de la parte dedicada al marqués llevara algún símbolo que recordara la unión hispano-americana ${ }^{108}$. Por su parte, Pelayo Quintero decía que "en la isla gaditana se exhibirá una obra de arte catalana", uniendo Barcelona y Cádiz, pues catalán era el escultor y el monumento fue labrado en Cataluña. El 19 de julio de 1918, en La Correspondencia de España se decía que la Comisión artística de la Junta para el monumento había aprobado el proyecto del escultor catalán "Pereda" (quiere decir "Parera") y que en octubre se pondría la primera piedra ${ }^{109}$.

El monumento fue contratado con el escultor Antonio Parera ${ }^{110}$, "vecino

107 José Manuel Pérez Sarmiento fue durante 43 años miembro del cuerpo diplomático de Colombia, ejerciendo en Venezuela, Francia y España; investigó en los archivos españoles, publicó libros (entre ellos un manual para el cuerpo diplomático), sostuvo la revista "Colombia" y pronunció numerosas conferencias. Falleció en Bogotá el 6 de mayo de 1948. El Congreso de Colombia aprobó la Ley 42 de 1948, de 16 de noviembre, para honrar su memoria.

108 La Gaceta de Tenerife, VIII, 2465 (15 de agosto de 1918), p. 1.

109 La Correspondencia de España, LXX, 22436 (19 de julio de 1918), p. 3.

110 Antonio Parera Saurina (Barcelona, 1868-1946), escultor y medallista, se formó en Madrid con el escultor Jerónimo Suñol y a partir de 1884 en la Academia de San Fernando, siendo 
de Barcelona y Catedrático de la Escuela de Industrias y Bellas Artes de dicha Ciudad", contrato que fue aprobado por la Comisión el 23 de septiembre de 1919. En dicho contrato se estipulaba que la cimentación quedaría a cargo de la Comisión o del Ayuntamiento, y el escultor se comprometía a modelar y dirigir la construcción del monumento. Éste emplearía en "la gradinata", tazas de la fuente y contrafuertes, una piedra caliza más oscura que el resto, para resistir los efectos del agua. Desde la base, donde estarían situados un cóndor y un león, hasta donde se asentaría el Genio del Cristianismo se utilizaría la piedra de Murcia, azulada clara. El busto del marqués sería de mármol blanco de Carrara; la figura terminal, dos relieves y medallones serían de bronce; y la cruz y el ramo de olivo, del Genio, se harían de bronce dorado al fuego. El monumento, elevado sobre un parterre, mediría 10 metros de altura y 7,50 de anchura.

La primera piedra fue colocada el 8 de octubre de 1919111. El Ayuntamiento, como estaba estipulado, se encargó de la cimentación; se abrió una cripta, donde habría de colocarse una biblioteca hispano-americana; y la base se construyó de mármol oscuro de Figueras, resistente a la humedad, mientras el resto del monumento se haría de piedra azulada de Murcia.

En julio de 1920 se produjo una reunión de la Comisión organizadora del homenaje a Claudio López, presidida por el alcalde de Cádiz, Francisco Clotet. En ella, "la maqueta del Monumento se acordó traerla a Cádiz para exponerla ante el público que desee apreciar las bellezas en la Real Academia Hispano-Americana de Ciencias y Artes"112. Fue el propio marqués quien retrasó la ejecución del monumento al negarse a posar para el escultor, quien tuvo que pedir en dos ocasiones al delegado de la Trasatlántica una fotografía de Claudio López. Cuando por fin se le envió la fotografía, el escultor contestó agradeciéndosela a Juan Carlos García de Sola el 20 de diciembre de 1920:

"Ahora precisamente estoy trabajando en el busto del homenajeado, y como puede suponer, todos cuantos elementos de consulta pueda alcanzar serán en beneficio de mi obra, ya que dada la extremada modestia del Sr. Marqués, hace que yo no pueda obtener de él un estudio personal de su cabeza, por juzgar dicho Sr. que no debe prestarse a ningún trabajo que tienda a dar facilidades a la preparación de un homenaje a su persona. Yo aplaudo su actitud y la

pensionado en Roma durante cuatro años a partir de 1888. Fue profesor de la Escuela de la Lonja de Barcelona desde 1897 y académico de las academias de Bellas Artes de San Jorge, San Fernando e Hispanoamericana (Cádiz). Estilísticamente evolucionó desde el clasicismo griego al modernismo. Desarrolló escultura religiosa, especialmente tras la guerra civil, y colaboró en varios monumentos: el de Alfonso XII en el Retiro de Madrid (donde hizo dos grupos escultóricos); el de los Asediados en Gerona; y otro en la Plaza de Cataluña (grupo de Gerona).

111 Según el diario El Sol (13 de agosto de 1919), p. 3, la primera piedra se colocó el día 12 de agosto de 1919.

112 El Correo de Cádiz, XII, 4088 (14 de julio de 1920), p. 2. 
admiro, pero como artista encargado del monumento, no, pues la falta de datos restará forzosamente valor y mérito a mi obra"113.

A la dificultad de conseguir la fotografía del marqués se unió la escasa recaudación recogida por la suscripción abierta, especialmente en Barcelona, y hubo que acudir a un llamamiento a nuevos suscriptores, empezando por el rey y siguiendo por las altas autoridades, obispos, empresarios, etc., y esta vez se consiguió una cantidad suficiente ${ }^{114}$. En el periódico La Libertad del 28 de marzo de 1920 se informaba de que en breve llegaría a Cádiz el vapor Legazpi con 108 bultos que contenían el monumento del marqués ${ }^{115}$. Y en La Veu de Catalunya del 5 de agosto de 1922 se indicaba que ese día había quedado terminado el monumento al marqués de Comillas en Cádiz y "el projecte del monument es de l'escultor senyor Parera, havent fet els treballs l'escultor de Barcelona Joan Senable" 116 .

El monumento fue inaugurado el 12 de octubre de 1922, sin la presencia del marqués, al parecer en París para no tener que asistir, y la presidencia del infante don Carlos en representación del rey. En la inauguración del monumento el busto se hallaba cubierto por un tapiz pintado por Manuel Leal, en el cual, rodeado por una orla de estilo Renacimiento con los escudos de las Repúblicas hispano-americanas, se destacaba una Matrona, que representaba a Cádiz, cobijada bajo el pendón morado de Castilla, la cual señalaba en un mapa el camino hacia América; y se veía también la nao Marigalante.

El monumento está descrito en el libro conmemorativo publicado en 1924 por la Comisión Organizadora del homenaje a Claudio López:

"Sobre un basamento de planta irregular y dispuesto con especial maestría, según la importancia de cada símbolo, tenemos la agrupación que mantiene la idea representada: naves róstratas indican el carácter marítimo de la ofrenda: las bellas figuras de matronas representando a España y América con el león y el cóndor a los pies y el retrato de Cervantes en el centro, significan el pueblo hispano-americano unido por el idioma: la matrona sentada en curul asiento, protegiendo a un niño desnudo, al que muestra un gran libro, y tocada con guerrero casco y piel de león, es la Hispania engendradora de la Raza que acoge e instruye al elemento autóctono en vez de destruirlo, cual hicieron otras naciones. A los lados vemos dos grandes relieves que representan dos barcos, uno es la nao Marigalante, capitana de Colón en su segundo viaje; otro es el

113 Las cartas, de 20 de diciembre de 1920 y 14 de febrero de 1921 en Biblioteca de Temas Gaditanos "Juvencio Maeztu", de Cádiz. Publicado por FAES DÍAZ, Enrique, Claudio López Bru..., p. 331.

114 Listas de suscriptores en Barcelona fueron publicadas en distintos números de La Veu de Catalunya, por ejemplo el 13 de septiembre de 1922, cuando se llevaban recaudadas 123 154,67 pesetas, y no fue la última lista.

115 La Libertad (28 de marzo de 1920), p. 3.

116 La Veu de Catalunya, 32, 8225 (5 de agosto de 1922), p. 8. 
vapor Cantabria, primero de la Compañía que partió de Cádiz para América.

Toda esta agrupación armoniosamente compuesta y sencillamente modelada, forman el basamento de donde arranca un gran pilar ante el cual sobre una columna de orden dórico (-es de orden jónico-) está el sencillo busto del Marqués labrado en mármol de Carrara. Decoran el pilar en su parte superior los escudos de España, Cádiz, Comillas y Academia Hispano-Americana y la parte posterior un medallón sobre un ancla y laureles con el busto de Colón. Corona y remata el Monumento una estatua en bronce inspirada en las clásicas representaciones de la Victoria, significando el Genio del Cristianismo, porque sin él no había Hispanoamérica y porque él es quien preside las grandes acciones" 117 .

Frente a las críticas de que la figura de Claudio López fuera sólo un busto, Pelayo Quintero Atauri, en el prólogo al libro conmemorativo del monumento, decía que el busto estaba situado en el centro del monumento y que era de mármol de Carrara, el material más noble empleado en este tipo de obras, y que se correspondía con la modestia del homenajeado. Justificaba que se hubiera levantado un monumento a alguien vida:

"Habrá, seguramente, muy pocas personas que en vida merezcan, como merece el Marqués de Comillas, el que su patria les dedique un Monumento artístico que sirva para recordar algo de cuanto se debe al esfuerzo generoso de tan benemérito patricio".

Y subrayaba que el monumento se hizo por suscripción pública, sin apoyo oficial (hubo Comisiones para recaudar fondos en Barcelona y Cádiz).

El monumento estaba dedicado al marqués, pero inmerso en un mensaje de exaltación hispano-americana. Quintero Atauri decía que el monumento "es un emblema de paz", y destacaba su "carácter hispano-americano". Se había tenido en cuenta que de Cádiz había partido el segundo viaje de Colón, no para descubrir, sino para poblar y civilizar; también que en Cádiz tenía la Compañía Trasatlántica sus astilleros; y que Cádiz y la Compañía Trasatlántica fueron casi el único medio de comunicación con América "durante el cataclismo pasado" (guerra de Cuba).

En su pedestal sobresalen las proas de dos naves que representan las de Colón, que partió de la bahía de Cádiz en su segundo viaje a América; un león y un cóndor a los pies de dos matronas simbolizan a España y América, unidas por el retrato de Cervantes, que unifica los dos continentes mediante la lengua. En un lateral se representa en bronce el vapor-correo Cantabria, el primero de la Compañía Trasatlántica que viajó de Cádiz a América, y posteriormente embarrancó en La Gomera el 5 de marzo de 1862 cuando transportaba a Cuba al batallón San Marcial, siendo rescatado por un barco ruso. Y en el lado contrario, también en relieve en bronce, la nao Marigalante,

117 Monumento al Marqués de Comillas. Memoria descriptiva del Monumento y de los trabajos realizados por la comisión organizadora, Cádiz, Rodríguez de Silva, 1924. 
capitana de Colón en su segundo viaje a América

Por encima, sobre una columna jónica, se halla el busto del marqués. Miguel Gascón, en 1925, recoge palabras de Parera: “En la parte anterior se da al busto del señor Marqués de Comillas el carácter sobrio y austero, que tan bien cuadra con sus virtudes"118. En la parte posterior del monumento figura una matrona que acoge a un niño con su derecha y sostiene un libro con su izquierda, representando a España que protege a América con las Leyes de Indias; y encima de este grupo un relieve con el retrato de Colón. Remata el monumento una "Niké" o "Victoria" alada, figura femenina que representa el "Genio del Cristianismo"119. El libro de François-René Chateaubriand titulado El Genio del Cristianismo, publicado en 1802, tuvo una enorme influencia en el catolicismo del siglo XIX y principios del XX, y también en la ideología de Claudio López y su entorno. Chateaubriand citaba allí al cristianismo como motor del progreso y también la superioridad del arte cristiano sobre cualquier otro tipo de arte. El monumento representa en su conjunto la ideología del segundo marqués de Comillas al coronarse con la representación del cristianismo y no con su busto, lo que contrasta con los monumentos dedicados a su padre en Comillas, Barcelona y Matagorda, que se coronaban con la estatua del primer marqués.

La crítica surgió donde nadie la esperaba, de un sector católico que no quería ni estatuas ni monumentos. En Catalunya Social, el 11 de julio de 1925 se publicó un artículo titulado "El monument al Marquès de Comillas", donde se decía que mejor que un monumento con estatuas y lápidas, había que hacer una "fundación de propaganda de la fe y de defensa del orden"; y "Res d'estàtues, ni de làpides, que el temps i la malicia dels homes corsequem i destrueixen fatalment" ${ }^{\prime 20}$. Pero en Cádiz se seguía insistiendo en 1925 en el homenaje al marqués, y allí la Real Academia Hispanoamericana de Ciencias y Artes organizó un certamen, cuyo primer tema era una poesía bajo el título de "El caballero cristiano"; el segundo, una "Biografía del marqués"; el tercero, "Labor hispano-americana del marqués de Comillas"; el cuarto, "El marqués de Comillas y la cuestión social"; y el quinto, "Retrato al óleo del marqués de Comillas"121.

Otro monumento a Claudio López fue erigido inmediatamente después de su fallecimiento, en 1925, en Bustiello (Asturias), un poblado minero mo-

118 GASCÓN, Miguel, Luz sin sombra..., p. 18.

119 La iconografía del monumento, descrita por Enrique Deschamps en su artículo "Americanismo práctico y fecundo", La Esfera IX, 444 (8 de julio de 1922), p. 8. Publica la maqueta del monumento.

120 Catalunya Social, 218 (11 de julio de 1925), p. 11.

121 El Cantábrico (10 de octubre de 1925). 
delo erigido por la Sociedad Hullera Española (Fig. 13). Antonio López había fundado en 1881 la Sociedad, que adquirió las minas de Aller (concejo de Mieres, Asturias). En 1936, el coto minero de Aller tenía 10 concesiones carboneras con una producción anual de 900000 toneladas y empleaba a 4000 obreros y a 311 técnicos y administrativos; poseía un ferrocarril de vía estrecha de 20 kilómetros, cuatro fábricas de aglomerados y una de ovoides. Como equipamiento social, tenía seis grupos escolares dobles, para $300 \mathrm{ni}-$ ños y niñas, 9 economatos y un sanatorio para 20 camas. Una parte de este conjunto lo constituía el poblado de Bustiello para albergar a un grupo seleccionado de trabajadores, que incluía capilla neorrománica $(1890)^{122}$, el círculo obrero (1894), la casa del ingeniero (1898), la serie de casas de obreros (1898 y 1914), el hospital (1902), los colegios de niños (1906) y de niñas, economato, casa del médico, etc. En suma, todo un modelo de población minera, hoy bien conservado.

Tiene importancia el hecho de la ubicación del monumento en el propio poblado minero de la "Sociedad Hullera Española", un poblado descrito de forma idealizada el día de la inauguración del monumento:

"Bustiello es como un 'nacimiento' de juguete; con sus casitas chiquitinas y enjabelgadas puestas en hilera, con sus huertos y sus calles rectas y empedradas. Bustiello es una finca de juguete con su iglesia garbosa y coquetona y sus colegios nutridísimos y los chalets de los ingenieros; con su puente saltando sobre el turbulento río y sus caminitos trepadores"123.

Lo primero en levantarse fue la iglesia, y le siguió el "Círculo obrero" comenzado a construir en 1893, con la iglesia todavía en obras ${ }^{124}$. El 1 de diciembre de 1893 Claudio López y su primo Santiago López asistieron a la colocación de la primera piedra del "Círculo", concebido como una alternativa lúdica y cultural a la "taberna", considerada como la perdición de los obreros.

Era en definitiva este poblado una muestra del paternalismo empresarial propuesto como modelo de sociedad católica. Y el complejo minero de Aller fue un "dique" en la confrontación con el movimiento obrero socialista, viviéndose momentos de gran violencia durante las sucesivas huelgas, sobre

122 "Termina de colocarse con brillante solemnidad la primera piedra de una nueva iglesia que a expensas del Excmo. Sr. Marqués de Comillas se va a levantar en su importante coto minero conocido en esta zona industrial con el nombre de 'Minas de Aller'". La Unión Católica, IV, 1107 (16 de diciembre de 1890), p. 2. Curiosamente, un artículo de Francisco Valles Antuña en El Siglo futuro, diario católico, del 9 de septiembre de 1887 (XIII, 3749, p. 1) expresaba la queja de que en las minas del marqués de Comillas no se respetaba el descanso dominical, impidiendo que los obreros pudieran acudir a Misa. Al contrario, citaba, las fábricas de Mieres y La Felguera, tenían iglesia y capellán.

123 Región, IV, 1084 (5 de diciembre de 1926), p. 2.

124 El Suplemento (tradicionalista), II, 139 (2 de diciembre de 1893), p. 3. 
todo en 1919-20. “Para los socialistas de los otros cotos -escribió Bayle- , Aller equivalía a un dique. Intentaron socavarlo y lo consiguieron en parte. Es un episodio que costó sangre y se comentó largamente en España".

El monumento en Bustiello se erigió en 1925, año de la muerte de Claudio López (aunque se inauguró en 1926), siendo obra del escultor Alfredo Marinas (Segovia, 1866-Madrid, 1953) ${ }^{125}$. Representa en bronce la ofrenda floral de un obrero al patrono, que figura en busto de bronce sobre una base de piedra, y que contiene la dedicatoria del "personal de las minas de Aller"126. El busto del marqués está tomado de la fotografía de Kaulak con el uniforme de la Orden de la Espuela de Oro. La verja que rodea el monumento está formada por los símbolos del trabajo minero, el pico y la pala. La forma del pedestal es un bloque de mármol a medio desbastar, y por delante un obrero tiende una corona vegetal al homenajeado ${ }^{127}$.

El monumento fue inaugurado el 4 de diciembre de 1926, día de Santa Bárbara. Forma parte de la exaltación de Claudio López como patrono católico ejemplar, la tesis defendida por el jesuita Sisinio Nevares Marcos ${ }^{128}$ en su libro El patrono ejemplar. Una obra maestra de Acción Social (Madrid, Razón y Fe, 1936).

Al poco tiempo de fallecer el marqués, hubo también un proyecto de monumento a Claudio López que se pretendía ubicar en la Universidad Pontificia de Comillas, en el centro de la plazoleta delante de la fachada del Seminario Mayor, sobre el promontorio "que a manera de Acrópolis se contempla desde el Palacio y carretera" y "a manera de atalaya que como la Minerva de Fidias defendía la Acrópolis". Un escultor, del que ignoramos su nombre, planteó allí un monumento modesto, aunque su intención era hacer uno "de mayores vuelos", a falta de conocer la opinión de la Compañía de Jesús. El escultor consideraba su proyecto como obra de concepción y sobriedad mo-

125 Aniceto Marinas estudió en la Academia de Bellas Artes de San Fernando desde 1884 y fue luego Pensionado en Roma (1888-93), siendo posteriormente Catedrático de la Escuela de Artes y Oficios de Madrid. Realizó varios monumentos públicos, como los de Alfonso XII en Madrid (1905), del Sagrado Corazón en el Cerro de los Ángeles (Getafe, 1919) o el de Velázquez, junto al Museo del Prado.

126 La inscripción dice: "Al Señor D. Claudio López Bru marqués de Comillas del personal de las minas de Aller. 1925".

127 Una amplia descripción en Región, IV, 1084 (5 de diciembre de 1926), pp. 2-3.

128 Sisinio Nevares Marcos (Carrión de los Condes, 1878 - Valladolid, 1946) ingresó en la Compañía de Jesús en 1893, siguiendo cursos en Carrión, Burgos, Veruela, Tortosa y Oña, siendo ordenado sacerdote en 1908. Fue profesor en Deusto, desde donde tomó contacto con la realidad obrera de las minas vizcaínas. En Palencia fundó numerosos sindicatos agrarios católicos y en 1915 fundó en Valladolid la Casa Social Católica. Promovió la creación de la Confederación Nacional Católico-Agraria, reunión de los sindicatos católicos agrarios. A partir de 1925 comenzó a publicar, especialmente en Razón y Fe, y dirigió la Casa de Escritores jesuitas. Colaboró en Fomento Social y Acción Católica. 
derna, "dentro de los más avanzados credos artísticos", sin extravagancias. Tendría "medio busto" del marqués, de mármol, sobre un pilar cuadrado "a modo de estela", de piedra de Escobedo de tono dorado. En el frente se situaría en bajorrelieve una matrona, representando a la Universidad, descubriendo su rostro apenado, cubierto con crespones de orfandad, con corona de bronce dorado, llevando en la mano una corona de siemprevivas con una cinta en la cual se situaría la leyenda en bronce dorado, "En eterna memoria". En los costados, sendas cabezas de Hermes, con dos niños representando la Marina Mercante y la alta Industria, representación del "Genio del Marqués de Comillas" y su munificencia en la caridad. Las cabezas de los Hermes serían de expresión doliente, con las cuencas de los ojos vacíos, por donde correría el agua en gotas hasta un espacio donde se podría plantar un rosal silvestre, que quedaría como "rocío de los Hermes". En la base del frente y del dorsal habría un ramillete de violetas. En el dorsal, se colocaría una placa de bronce dorado al fuego, donde se inscribirían los nombres de los donantes del monumento. Según el autor del proyecto, el aspecto "demasiado funerario" quedaba justificado por "la ideología moral y cristiana de D. Claudio López y Brú y la protección paternal que tuvo para los moradores de la Universidad Pontificia", características del finado que "le dan derecho a que este monumento sea el testimonio de aquellos que le amaron, que no una pomposa manifestación de vanidad" ${ }^{129}$.

\section{HACIA LA BEATIFICACIÓN}

La imagen de un santo moderno precisaba de una reflexión. Recoge Eduardo Fernández Regatillo, postulador de la causa de la beatificación de Claudio López, que en una ocasión, Pedro Pablo de Alarcón, miembro de la Junta Central de Acción Católica, preguntó: “¿Cómo representarán al Marqués de Comillas, cuando le pongan en los altares? Porque un santo de levita parece que no pega". Y también recoge el testimonio de Manuel Arnús, que decía: "Con el Marqués no se puede negociar, pero como es San Claudio, hay que dejarle" ${ }^{130}$. Sin duda era mejor representarle figuradamente por su santo patrono.

Eduardo Llorens Masdeu fue el pintor preferido por la familia López, tanto en Barcelona (Palacio Moja) como en Comillas (Palacio de Sobrellano; Seminario), y en 1892 firma cuatro tablas que formarían parte de los retablos de la iglesia del Seminario, con los santos patrones de diversos miembros de la familia López, entre ellos San Claudio. Los cuadros son óleos sobre tabla y presentan las figuras sobre fondo dorado con aplicación de yeso en relieve

129 AHUPC, leg. H-157.

130 FERNÁNDEZ REGATILLO, Eduardo, “Causa de beatificación..., pp. 804-814. 
a modo de tapiz vegetal, imitando a la pintura gótica del siglo XV, pero la figura deriva de un grabado del "Año Cristiano" que representa a San Victoriano, también con vestimenta militar ${ }^{131}$. Con este cuadro quedaba representado Claudio López en la iglesia de la Universidad Pontificia de Comillas por medio de su santo patrono, en compañía de gran parte de su familia, igualmente a través de sus patronos.

Claudio López falleció el 18 de abril de 1925, y fue enterrado en primera instancia en la Capilla-panteón del palacio de Sobrellano. Allí, “el cuerpo del benemérito patricio quedó depositado en la sepultura superior a la en que yace su madre, la marquesa viuda de Comillas, fallecida el 5 de octubre de $1905^{\prime \prime 132}$. Posteriormente sus restos fueron llevados a una capilla de la iglesia pública de la Universidad Pontificia de Comillas ${ }^{133}$, para regresar finalmente a la Capilla-Panteón. Pero nunca se hizo para él un panteón con un grupo escultórico propio (actualmente se halla bajo un Cristo yacente de Agapito Vallmitjana que no le corresponde, pues es de fecha muy anterior al fallecimiento del marqués), y este hecho muestra una determinada idea religiosa de "humilitas" que tiene una larga tradición con la que Claudio López se sentiría identificado.

En líneas generales, la influencia de la Compañía de Jesús sobre los comportamientos de Claudio López resulta indudable. Los Ejercicios Espirituales de San Ignacio, al describir tres tipos de humildad, rechazan el "querer la honra"134, prefiriendo "el oprobio con Cristo cubierto de oprobios en lugar de honores"; pero se declara que la humildad no es un bien absoluto y está limitada por el "servicio de Dios". Santo Tomás había incorporado la idea de la superioridad del "bien común" sobre el "bien privado", y por tanto la subordinación de las virtudes privadas al bien común, que puede exigir magnificencia. La Compañía de Jesús ya introdujo esta consideración en 1550 y la mantendría a lo largo de su historia. Ser representado Claudio López como "miles christi"135 en su imagen más significativa elegida por los

131 CROISSET, Juan, Año Cristiano o ejercicios devotos para todos los días del año, Vol. I, Madrid, Imprenta de Gaspar y Roig, 1852. Trad. de José Francisco de Isla, revisado por Justo Petano y Mazariegos. Grabado entre páginas 490 y 491.

132 El Cantábrico, XXXI 11225 (21 de abril de 1925), pp. 1-2. En este artículo figuran fotografías del traslado de los restos de Claudio López a Comillas y una en la que figura el monumento funerario de Antonio López, primer marqués, señalando, equivocadamente, que es el que acogió los restos de Claudio.

133 Diario de Burgos, LXXXVII, 56647 (24 de julio de 1977), p. 34. El Padre Cándido Marín propuso en 1947 trasladar al Seminario los restos de Claudio López y del Padre Tomás Gómez. Carta de Cándido Marín S.J. a Juan B. Jansens, en Roma. Logroño, 30 de junio de 1947. AHUPC, leg. 156 (carpeta 2).

134 La honra es el reconocimiento público del honor.

135 San Pablo (Carta a los Efesios, 6,11-17); Erasmo de Rotterdam (Enchiridion Militis Christiani, 1503). 
jesuitas (Aula magna del Seminario de Comillas), significaba manifestar estar públicamente al servicio de Dios, dejando la humildad privada en segundo plano.

Pero además existía una larga tradición filosófica y literaria que exaltaba la compatibilidad entre la austeridad privada ("pietas", "mores") y la magnificencia pública ("publica magnificentia") según el concepto del "decorum”, es decir la adecuación de la obra al fin propuesto y a lo que representa. Algunos gobernantes ya lo habían puesto en práctica (el emperador Augusto; Felipe II...). Manifestándose como austero en la vida privada y magnífico en lo público, Claudio López seguía así ideas neoestoicas, uniendo esta tradición de austeridad y magnificencia con la de la humildad religiosa y el servicio de Dios.

\section{Bibliografía}

ABAD, Camilo María S.J., El Seminario Pontificio de Comillas. Historia de su fundación y primeros años (1881-1925), Madrid, Tipografía Católica, de Alberto Fontana, 1928.

ÁLVAREZ LAITA, Francisco Javier, "Implicaciones industriales del plan de Escuadra Maura-Ferrándiz", en Plan Ferrándiz. Poder Naval y Poder Marítimo, XXXVII Jornadas de Historia Marítima, Cuadernos monográficos del Instituto de Historia y Cultura Naval 57, Madrid, 2008, pp. 65-86.

ARNÚS, María del Mar, Comillas, preludio de la modernidad, Madrid, Electa, 1999.

ASÚA, Miguel de, El Marqués de Comillas. Biografía, Cádiz, Real Academia Hispanoamericana de Ciencias y Artes, 1926.

BAYLE, Constantino, El segundo marqués de Comillas Don Claudio López Bru, Madrid, Razón y Fe, 1928.

BLOND GODOY, María África, "Federico Godoy, su vida y su obra", Anales de la Universidad de Murcia, 53-54 (1967), pp. 323-358.

BORZELLO, Frances, En casa. El interior doméstico en el arte, Barcelona, Electa, 2006.

CANCIO, Jesús, "La Universidad Pontificia de Comillas", en La Esfera, XII, 587, 4 de abril de 1925, pp. 25-26.

CASTROVIEJO NOBAJAS, Amando R., Peregrinación obrera española a Roma en 1894. De Granada a Roma y regreso. Tres semanas de Peregrinación, prólogo de Francisco Javier Simonet, Granada, imprenta de López Guevara, 1894.

CROISSET, Juan, Año Cristiano o ejercicios devotos para todos los días del año. Trad. de José Francisco de Isla, revisado por Justo Petano y Mazariegos, Vol. I, Madrid, Imprenta de Gaspar y Roig, 1852.

CUÉ, Ramón S.J., Comillas. Itinerario-Lírico, Santander, Aldus, 1942.

EISMAN LASAGA, Carmen, "La permanencia de la tradición en la pintura de retrato de Joaquín Diéguez", El arte español en épocas de transición, IX Congreso Nacional CEHA, León, 29 de septiembre a 20 octubre 1992, Tomo II, Universidad de León, 1994, pp. 473-480.

El Seminario y Universidad Pontificia de Comillas en el XXV aniversario de su fundación. 
1892. Álbum conmemorativo. 1917, Barcelona, Sociedad General de Publicaciones, 1918.

FAES DÍAZ, Enrique, “Poder político y poder económico en la Restauración: una interpretación divina (la singular formulación del segundo Marqués de Comillas", Historia y política. Ideas, procesos y movimientos sociales, 9 (2003), pp. 9-39.

FAES DÍAZ, Enrique, Claudio López Bru, Marqués de Comillas, Madrid, Marcial Pons, 2009.

FERNÁNDEZ REGATILLO, Eduardo, Posiciones y artículos para el proceso sobre la fama de Santidad, virtudes y milagros del siervo de Dios Claudio López Brú, marqués de Comillas, Santander y Madrid, Aldus, 1943.

FERNÁNDEZ REGATILLO, Eduardo, "Causa de beatificación del Marqués de Comillas", Sal Terrae, XXXV, (dic. 1947), pp. 804-814.

FERNÁNDEZ REGATILLO, Eduardo., Un marqués modelo. El Siervo de Dios Claudio López Bru, segundo Marqués de Comillas, Santander, Sal Terrae, 1950.

GARCÍA-MARTÍN, Manuel, Comillas modernista, Barcelona, Catalana de Gas, 1993.

GASCÓN, Miguel, Luz sin sombra. El Marqués de Comillas, Comillas, Sal Terrae, 1925.

GONZÁLEZ CALLEJA, Eduardo y REY REGUILLO, Fernando del, La defensa armada contra la revolución. Una historia de las guardias cívicas en la España del siglo XX, Madrid, CSIC, 1995.

GONZÁLEZ ECHEGARAY, Rafael, Los tres Comillas, semblanza biográfica de tres buques gemelos, Madrid, Estades Artes Gráficas, 1962.

GONZÁLEZ CAMINERO, Nemesio, La pontificia Universidad de Comillas, Comillas, Aldus, 1942.

GUIJAR Y VELASCO, Santiago, Un viaje a Roma. Peregrinación obrera española o sea el triunfo de la Religión, Valladolid, Imp. de Leonardo Miñón, 1896.

GUTIÉRREZ DÍAZ, Francisco, "Un pintor decimonónico afincado en Santander. José Sánchez y Sánchez", Altamira, 73 (2007), pp. 231-256.

HERNÁNDEZ SANDOICA, Elena y MANCEBO, María Fernanda, “El empréstito de 1896 y la política financiera en la guerra de Cuba", Cuadernos de historia moderna y contemporánea 1 (1980), pp. 141-170.

KENT, Conrad, "Claudio López y Eusebio Güell: industriales como forjadores de cultura", en CIPLIJAUSKAITÉ, Biruté y MAURER, Christopher (eds.), La voluntad de humanismo. Homenaje a Juan de Marichal, Barcelona, Anthropos, 1990, pp. 107-120.

La guerra hispano-yanqui. Álbum episódico, ilustrado con 196 grabados, ed. La Vanguardia, Barcelona, tomo XIV, (¿1898?).

MARCHI, Maria Barbara, Cercle Artístic de San Lluch 1839-2009: historia d'una institució referent per a la cultura barcelonina, Tesis Doctoral, Dept. de Historia del Arte, Universitat de Barcelona, 2011.

MAURA Y GAMAZO, Gabriel, Pequeña historia de una grandeza. El Marqués de Comillas, Barcelona, José Porter, 1949.

Monumento al Marqués de Comillas. Memoria descriptiva del Monumento y de los trabajos realizados por la Comisión Organizadora, Cádiz, Rodríguez de Silva, 1924.

NEVARES MARCOS, Sisinio, El patrono ejemplar. Una obra maestra de Acción Social, Madrid, Razón y Fe, 1936. 
OSSORIO Y BERNARD, Manuel, Galería biográfica de artistas españoles del siglo XIX, vol. I, Madrid, Imprenta de Ramón Moreno, 1868.

PAPÀSOGLI, Giorgio, Il Marchese di Comillas, Torino, Marietti Editori, 1959.

PAPÀSOGLI, Giorgio, El marqués de Comillas: Don Claudio López Bru, Madrid, Publicaciones de la Universidad Pontificia Comillas, 1984.

PENSADO, Berta, El Marqués de Comillas, Madrid, Temas Españoles 83, 1954.

Plan de señales para la flota de A. López y Comp ${ }^{\underline{a}}$ que ha de maniobrar frente a Comillas en presencia de S.M. el Rey, Santander, José M. Martínez, 1881.

RODRIGO ALHARILLA, Martín, Los Marqueses de Comillas, 1817-1925. Antonio y Claudio López, Madrid, Lid, 2001.

SAMA, Antonio, "Nuevas noticias sobre el joven Gaudí: los kioskos de Comillas", Boletín de la Institución Libre de Enseñanza, 2a época, 11 (abril 1991), pp. 37-52. 